\title{
FUNDACJA BISKUPA STEFANA WIERZBOWSKIEGO DLA BERNARDYNÓW W GÓRZE KALWARII KOLO WARSZAWY
}

Powstanie kościołów i kaplic Męki Pańskiej czyli tzw. Nowej Jerozolimy w powiecie czerskim koło Warszawy w drugiej połowie XVII w. było dziełem biskupa poznańskiego Stefana Wierzbowskiego, który wzorując się na Jerozolimie w Ziemi Świętej i na polskiej Kalwarii Zebrzydowskiej ${ }^{1}$ oddał główny kościół i kilka kaplic dróżkowych w opiekę Zakonu Braci Mniejszych Prowincji Małopolskiej (popularnie: Bernardynów). Pozostałe kościoły kalwaryjskie powierzył: Dominikanom Obserwantom, Filipinom (po ich odejściu: Księżom Życia Wspólnego czyli tzw. Bartoszkom), Pijarom i Marianom. Początki fundacji bernardyńskiej w Górze Kalwarii miały miejsce w $1670 \mathrm{r}$., a dokładniej - przyjęcie propozycji biskupa fundatora przez zarząd zakonnej prowincji nastapiło podczas obrad kapituły intermedialnej w Krakowie na Stradomiu w dniu 16 listopada tegoż roku. Odczytano wówczas potrójną korespondencję biskupa z zarządem prowincji i wyznaczono komisję dla przeprowadzenia wizji lokalnej „w dobrach jego dziedzicznych w Górze koło Czerska" . W ten sposób doszło do oficjalnej wstępnej akceptacji warunków fundacji, która po załatwieniu formalności prawnych, wydaniu dokumentu przez fundatora i oblatowaniu go w urzędzie grodzkim w Czersku - dotrwała do roku 1873 czyli do likwidacji konwentu po powstaniu styczniowym (1863) przez władze rosyjskie.

BISKUP STEFAN WIERZBORSKIFUNDATOR NOWEJ JEROZOLIMY

Fundator sanktuarium pasyjnego w Górze Kalwarii koło Warszawy, biskup poznański Stefan Wierzbowski był synem kasztelana inowłodzkiego Mi-

${ }^{1}$ Kalwaria Zebrzydowska stanowiąca zespół kościołów i kaplica tzw. Dróżki Męki Pańskiej, została ufundowana przez Mikołaja Zebrzydowskiego h. Radwan w 1602 r. Pierwsza kaplica Ukrzyżowania na wzór jerozolimskiej powstała na wzgórzu Ukrzyżowania, czyli u podnóża Góry Żar (Włodkowej) już o rok wcześniej - H. E. W y c z a w s k i OFM, Kalwaria Zebrzydowska. Historia klasztoru Bernardynów i kalwaryjskich Dróżek, Kalwaria Z. 1987, s. 59.

${ }^{2}$ Archiwum Prowincji OO. Bernardynów w Krakowie (dalej APBK) Rkp. M-7: Akta Prowincji Małopolskiej Bernardynów, 1659-1686, s. 139. 
kołaja Wierzbowskiego i Urszuli z domu Grudzińskiej. Urodził się w Lasku k. Sieradza w 1620 r. Po wstapieniu do stanu duchownego i przyjęciu święceń kapłański rozpoczął karierę duchowną jako archidiakon łucki (1653). Został następnie kanonikiem katedralnym krakowskim oraz referendarzem koronnym. Kapituła katedralna poznańska wybrała go biskupem swojej diecezji w 1663 r. Prekonizację Stolicy Apostolskiej na biskupstwo poznańskie otrzymał w tymże roku i jako pierwszy $\mathrm{z}$ biskupów tejże diecezji rozpoczałł rezydować na stałe $w$ Warszawie ${ }^{3}$. Bez osobnej zgody papieża, a nawet wbrew protestom swojej kapituły katedralnej zaczął używać tytułu biskupa poznańskiego i warszawskiego. W 1666 r. wykupił od Mikołaja i Konstantego Górskich (h. Doliwa) wsie Górę i Wólkę Górską koło Warszawy, które lokował jako miasto na prawie magdeburskim, pod nazwą Nowa Jerozolima. Mogli się w nim osiedlać jedynie katolicy, co potwierdzał przywilej lokacyjny króla Michała Korybuta z 1670 r., zatwierdzony przez sejm w trzy lata później. Kolejny przywilej króla Jana III Sobieskiego z 1680 r. zaliczył Nową Jerozolimę do miast królewskich. Biskup Wierzbowski zbudował w Górze Kalwarii własną rezydencję i ufundował kościoły i kaplice wedhug planu jerozolimskiego i na wzór kaplic dróżkowych w Kalwarii Zebrzydowskiej. Do ich obsługiwania sprowadził zakonników $\mathrm{z}$ kilku zakonów, których rozmieścił $\mathrm{w}$ różnych klasztorach wybudowanych na trasie dróżkowej. Na krótko przed śmiercią w 1687 r. biskup Wierzbowski otrzymał nominację króla Jana III na stolicę prymasowską w Polsce, której nie zdażył już objąć. Zmarł z 6 na 7 marca 1687 r. w Górze Kalwarii i został pochowany w kościele Św. Krzyża na wzgórzu Ukrzyżowania, a następnie przeniesiony wraz z tytułem kościoła parafialnego, do kościoła Znalezienia Krzyża Świętego, w Ratuszu Piłata ${ }^{5}$.

\section{FUNDACJA KOŚCIOŁA I KONWENTU \\ OJCÓW BERNARDYNÓW}

Kościół parafialny we wsi Góra w powiecie czerskim na Mazowszu, pod wezwaniem Wniebowzięcia Najświętszej Maryi Panny sięga swoimi początkami wieku XII. Pierwsza wzmianka, dokładnie datowana, pochodzi dopiero z 1252 r., kiedy to biskup poznański Bogufał II uposażył go kilkoma dziesięcinami z pobliskich wsi ${ }^{6}$. Był to kościół niewielki, drewniany, który w połowie XVII w. wymagał gruntownej odbudowy. Został odnowiony przez biskupa poznańskiego Stefana Wierzbowskiego w 1670 r., a następnie wraz $\mathrm{z}$ wybudowanym przy nim murowanym klasztorem, przekazany Zakonowi Braci Mniejszych z zakonnej Prowincji Małopolskiej, zwanych Bernardyna-

\footnotetext{
${ }^{3}$ J. N o w a c k i, Dzieje archidiecezji poznańskiej, t. 2, Poznań 1964, s. 108.

${ }^{4}$ Tamże; J. Ptak, M. Wrzeszcz, Góra Kalwaria, [w:] Encyklopedia Katolicka, t. 5, Lublin 1989, kol. 1371.

${ }^{5}$ Tamże; J. Nowacki, Dzieje archidiecezji..., s. 108.

${ }^{6}$ Tamze, s.524; (Nowakowski) W a claw z Sulgostow a OFMCap., O cudownych obrazach w Polsce Przenajświętszej Matki Bożej, Kraków 1902, s. 239.
} 
$\mathrm{mi}^{7}$. Budowe konwentu ukończono sumptem biskupa fundatora w $1679 \mathrm{r}$. Wraz z przekazaniem zakonnikom dotychczasowego kościoła parafialnego Wniebowzięcia NMP zaistniała potrzeba przeniesienia ośrodka parafii nowojerozolimskiej do innej świątyni, gdyż Bernardyni nie angażowali się jeszcze wtedy w pracy parafialnej i podobnie jak w Kalwarii Zebrzydowskiej mieli za zadanie obsługiwać przybywających tu pielgrzymów. W związku z tym biskup Wierzbowski, przynaglony dekretem Kongregacji do Spraw Interpretacji Soboru Trydenckiego, wydanym w $1676 \mathrm{r}$. w tej właśnie sprawie, przeniósł parafię do kościoła Świętego Krzyża na wzgórzu Ukrzyżowania Chrystusa. Do prowadzenia duszpasterstwa parafialnego sprowadził księży Oratorianów, w Polsce zwanych Filipinami, których umieścił w klasztorze przy tym właśnie kościele $^{8}$. Kongregacja kalwaryjska Filipinów powstała już w 1672 r., a uposażył ją biskup Wierzbowski w roku następnym ${ }^{9}$. Przekazał Filipinom parafię Świętego Krzyża z nowo wybudowanym kościołem pod tym samym wezwaniem na Górze Kalwarii czyli Ukrzyżowania Zbawiciela. Oprócz zwyczajnego duszpasterstwa parafialnego mieli zakonnicy obsługiwać też pielgrzymów, podobnie jak Bernardyni i inne zakony w Nowej Jerozolimie ${ }^{10}$. Każdorazowy przełożony kongregacji kalwaryjskiej kierował równocześnie duszpasterstwem parafii jako proboszcz, $\mathrm{z}$ oficjalnym tytułem prepozyta ${ }^{11}$. Miał on też władze sądowniczą patrymonialna, jako wyższa instancja w stosunku do sądu ławniczego w mieście Górze Kalwarii ${ }^{12}$. Kongregacja Filipinów w Nowej Jerozolimie istniała tylko do roku 1683 . Biskup fundator był zmuszony rozwiązać ją $\mathrm{z}$ powodu braku powołań ${ }^{13}$. W ich miejsce wprowadził Księży Życia Wspólnego zwanych popularnie Bartoszkami albo księżmi Komunistami ${ }^{14}$.

Przydzielony Bernardynom poparafialny kościół otrzymał charakter zakonnej świątyni, o czym świadczy między innymi ołtarz boczny św. Franciszka z Asyżu. W głównym ołtarzu zakonnicy umieścili obraz Ofiarowania Najświętszej Maryi Panny w świątyni jerozolimskiej, zmieniając na ten właśnie tytuł wezwanie kościoła. Poprzednie jego wezwanie Wniebowzięcia NMP Bi-

${ }^{7}$ Sprawa przynależności zakonnej kościoła i konwentu Bernardynów w Górze Kalwarii była początkowo przedmiotem sporu między Prowincją Wielkopolska a Małopolską Bernardynów. Ostatecznie załatwiono sprawę polubownie na kapitule zakonnej w Kalwarii Zebrzydowskiej, a następnie w Bydgoszczy w 1674 r. Góra Kalwaria została przydzielona na stałe do Prowincji Małopolskiej, za cenę ustappienia małopolskich Bernardynów z planów tworzenia w Warszawie własnego hospicjum. - K. K a n t a k, Bernardyni polscy, t. 2, Lwów 1933, s. 173.

${ }^{8}$ Archiwum Prowincji oo. Bernardynów w Krakowie (Dalej:APBK) Rkp. W-12: Akta Prowincji Wielkopolskiej Matki Bożej Anielskiej Bernardynów, XVIII-XIX w., s. 132.

${ }^{9}$ H. J a r o m in, Zarys historii Kongregacji Oratorium św. Filipa Neri w Polsce (1668-1968), „Nasza Przeszłośc” 32:1970, s. 86, 87.

${ }^{10}$ APBK Rkp. W-12, s. 133.

${ }^{11}$ H. J a r o m i n, Zarys dziejów Kongregacji Oratorium..., s. 87.

${ }^{12}$ Wszystkie nadania i przywileje Filipinów w Gorze Kalwarii zatwierdził król Michał Korybut w 1673 r. - tamże, s. 87.

${ }^{13}$ Tamże, s. 91.

${ }^{14}$ Księży Życia Wspólnego założył sługa Boży Bartłomiej Holzhauser ok. 1673 r. Od imienia założyciela nazwano ich populamie „Bartoszkami” - M. D a n i l u k, Holzhauser Bartholomaus [w:] Encyklopedia Katolicka, t. 6, Lublin 1993, kol. 1159, 1160. 
skup fundator przeniósł na jedną z kaplic dróżkowych w serii Matki Bożej na Górze Syjon, obshugiwaną przez ojców Dominikanów Obserwantów ${ }^{15}$. Umieszczając synów św. Franciszka przy odnowionym poparafialnym kościele, wprowadził ich uroczyście w dniu 30 marca $1670 \mathrm{r}$. (w niedzielę palmowa) ${ }^{16}$. Dał im również konwent murowany, jeszcze wówczas nie wykończony oraz 5 kaplic: przykościelną św. Waleriana Męczennika oraz św. Antoniego i św. Anny, umieszczone poza klasztornym ogrodem, jak również dwie bliżej nieokreślone kaplice, w serii pasyjnej ${ }^{17}$. Otrzymali też obowiązek zawarty w dokumencie fundacyjnym, przewodniczenia pielgrzymom podczas odprawiania Drogi Krzyżowej, ewentualnie podczas nabożeństwa dróżkowego przy kaplicach Matki Bożej Bolesnej. Także inne zakony osadzone przy niektórych kościołach na trasie dróżkowej, a więc Księża Wspólnego Życia zwani Bartoszkami sprowadzeni z Bawarii (1683), Dominikanie Obserwanci (1677) ${ }^{18}$, Pijarzy (1675), Marianie zwani tu „Wieczernikami” $(1677)^{19}$ - zostali również zobowiązani przez fundatora do oprowadzania i przewodniczenia pielgrzymom w nabożeństwie dróżkowym, ale tylko na wyraźną ich prośbę, gdyby zgłosili się do ich domu zakonnego i prosili o przewodnika ${ }^{20}$. Mieli też opiekować się i remontować kaplice, które im zostały przydzielone. Tego rodzaju obowiązki nie dotyczyły sióstr Dominikanek, które mieszkały w klasztorze przy kaplicy Domku Maryi w latach 1677-179421. Bernardyni zostali uznani przez biskupa Wierzbowskiego za opiekunów i gospodarzy całej Kalwarii góreckiej, a więc mieli obowiazek kierowania wszystkimi ważniejszymi akcjami duszpasterskimi na terenie dróżkowym, oraz czuwania nad całością 22 I od samego początku nasi zakonnicy przyjmując w pełni świadomie zobowiązania fundacyjne starali się wypełniać tę rolę koordynatorów jak najlepiej. Szerzyli kult pasyjny i Matki Bożej Bolesnej, urządzając nabożeństwa kalwaryjskie, szczególnie wystawne $\mathrm{i}$ dobrze przygotowane $\mathrm{w}$ okresie kończącym Wielki Post, w Wielkim Tygodniu. Nic jednak nie wiadomo, czy urządzali misteria pasyjne, jak to czynili już w wieku XVII w Kalwarii Zebrzydowskiej. W każdym razie organizowali na pewno uroczyste procesje pasyjne, z kazaniami przy ważniejszych kościołach i kaplicach, śpiewami o Męce Pańskiej i Matce Bożej Bolesnej, przy wtórze kapeli, zorganizowanej przy klasztorze w 1679 r. i utrzymywanej osobnymi nadaniami, zabezpieczonymi przez fundatora.

${ }^{15}$ APBK Rkp. W-12, s. 133.

${ }^{16}$ Opis źródłowy wprowadzenia Bernardynów do kościoła w Nowej Jerozolimie zamieszczamy po niniejszym artykule, w dodatku pt.: „Edycja źródła”.

${ }^{17}$ W. F. M u ra wi e c, Góra Kalwaria, [w:] Klasztory bernardyńskie w Polsce w jej granicach historycznych, pod red. H. E. Wyczawskiego, Kalwaria Z. 1985, s. 71; APBK Rkp. $\mathrm{W}-12$, s. 112. 1997 , s. 109.

${ }^{18}$ M. B or k o w s k a OSB, Klasztory dominikańskie w Górze Kalwarii, Góra Kalwaria

${ }^{19} \mathrm{H}$. J a r o m i n, Zarys historii Kongregacji Oratorium..., s. 87.

${ }^{20}$ APBK Rkp. W-12, s. 130.

${ }^{21}$ M. B o r k o w s k a OSB, Klasztory dominikańskie..., s. 16, 38.

${ }^{22}$ APBK Rkp. W-12, s. 131. 
Biskup Stefan Wierzbowski sam dał do oblaty dokument fundacyjny do akt grodzkich w Czersku, w 1672 r. jako "fundację z nowego fundamentu" (fundationem de nova radice) ${ }^{23}$. $\mathrm{Z}$ kolei w roku następnym fundację zatwierdził sejm Rzeczypospolitej obradujący w Warszawie ${ }^{24}$.

Kościół ojców Bernardynów w Nowej Jerozolimie pod zmienionym wezwaniem Ofiarowania Najświętszej Maryi Panny posiadał trzy ołtarze. Główny ołtarz z obrazem Ofiarowania Maryi w świątyni jerozolimskiej oraz dwa boczne: po lewej Matki Bożej z Dzieciątkiem, uważany za cudowny i po prawej ołtarz z obrazem świętego zakonodawcy - Franciszka z Asyżu. Obraz Matki Bożej przedstawia Maryję $\mathrm{z}$ berłem w prawej ręce i z Dzieciątkiem Jezus trzymanym lewą ręka. Dzieciątko Jezus trzyma kulę ziemską ${ }^{25}$. W 1765 r. było w kościele 64 wotów srebrnych i jedno złote, oraz 14 srebrnych bogato wyzłacanych różyczek $\mathrm{z}$ rubinami pośrodku ${ }^{26}$. Wchodząc do kościoła głównym wejściem, po lewej stronie znajdowała się drewniana kaplica św. Waleriana Męczennika, $\mathrm{z}$ marmurowym sarkofagiem i $\mathrm{z}$ relikwiami świętego. Przywiózł je z Rzymu sam fundator w 1673 r. Do najcenniejszych relikwii w tym kościele należała cząstka Krzyża Św. ofiarowana Bernardynom przez tegoż biskupa fundatora. Umieszczono ją w stosunkowo dużym srebrnym relikwiarzu w kształcie krzyża ${ }^{27}$.

W ścianie frontowej kościoła umieszczono zegar z dwoma dzwonami wybijającymi godziny i kwadranse ${ }^{28}$. Do budynków sakralnych obsługiwanych przez Bernardynów należały również dwie kaplice stojące poza parkanem ogrodowym - kaplica św. Antoniego z Padwy i kaplica św. Anny. Pierwsza $\mathrm{z}$ nich, fundowana przez biskupa Wierzbowskiego, $\mathrm{z}$ drewnianą figurą w ołtarzu, odznaczająca się dużą wartością artystyczną. Była obwieszona wotami dziękczynnymi. Wiadomo $\mathrm{z}$ opisu fundacji, iż kaplica ta stała na grobli przedzielającej dwa stawy konwenckie. O jej gruntownej restauracji dowiadujemy się pod data $1808 \mathrm{r}$. Przeprowadził ją gwardian tutejszy Salwator Blewski. Natomiast o kaplicy św. Anny nie posiadamy bliższych informacji poza lakonicznym stwierdzeniem, iż wraz z kaplicą św. Antoniego stała poza ogrodem klasztornym ${ }^{29}$. Mamy ponadto tu i ówdzie wzmianki o kaplicy św. Franciszka, która jeszcze stała w 1679 r., ale późniejsze źródła już jej nie wymieniają ${ }^{30}$.

\footnotetext{
${ }^{23}$ Tamże, s. 131, 137.

${ }^{24}$ W. F. M u raw i e c OFM, Góra Kalwaria..., s. 71

25 (Nowakowski) Wacław z Sulgostowa OFMCap., O cudownych obrazach..., s. 239.

${ }^{26}$ APBK Rkp. M-27: Thesaurus minoriticae paupertatis ecclesias ... Provinciae Minoris Poloniae exornans, s. 352; Rkp. W-12, s. 167.

${ }^{27}$ APBK Rkp. W-12, s. 112.

${ }^{28}$ Tamże, s. 168.

${ }^{29}$ W. F. M u r a w i e c OFM, Góra Kalwaria..., s. 71.

${ }^{30}$ APBK Rkp. W-12, s. 134.
} 
MARSZAŁEK WIELKI KORONNY FRANCISZEK BIELIŃSKI

I BUDOWA KOŚCIOEA MUROWANEGO

W NOWEJ JEROZOLIMIE

Pierwszy drewniany kościół odnowiony przez fundatora dla sprowadzonych tu Bernardynów uległ pożarowi i popadł w ruinę. W połowie XVIII w. był w stanie tak wielkiego zniszczenia, iż wymagał gruntownej przebudowy, myślano nawet o zastapieniu go zupełnie nową świątynią. Zarząd Prowincji Małopolskiej rozpoczał poszukiwania za nowym fundatorem, który by podjął budowę kościoła w Nowej Jerozolimie od fundamentów. W 1755 r., znaleziono takiego w osobie zasłużonego dla Warszawy, marszałka wielkiego koronnego, Franciszka Bielińskiego h. Junosza ${ }^{31}$. Miał on wprawdzie nie najlepszą sławę wśród duchowieństwa, jako atakujący księży za próby egzekwowania dziesięcin, ale sam zgłosił gotowość finansowania „fabricam ecclesiae” w Górze. Ponadto Bieliński domagał się od króla i prymasa, oddania wielu spraw rozstrzyganych dotychczas przez sądy duchowne, pod jurysdykcję sadów świeckich ${ }^{32}$. Dotyczyło to szczególnie władzy patrymonialnej nad świeckimi pracownikami w dobrach duchownych. Nie ulega wątpliwości, iż w dobie oświecenia było to działanie na rzecz równości wszystkich obywateli wobec prawa. Bernardyni jednak zgodnie z Regułą św. Franciszka, zawsze wyrzekali się tego rodzaju władzy patrymonialnej przy okazji przyjmowania każdej nowej fundacji. W momencie przyjmowania fundacji w Nowej Jerozolimie, takiego wyrzeczenia dokonał $\mathrm{w}$ imieniu zakonnej Prowincji Małopolskiej, o. Franciszek Kochanowski, lektor teologii, w 1679 r. ${ }^{33}$ Zakonnicy św. Franciszka nie mieli więc tego rodzaju uprzedzeń do władz świeckich, dlatego chętnie przyjęli w roku 1755 gotowość fundacji w Górze Kalwarii ze strony marszałka Bielińskiego ${ }^{34}$. Jego sumptem wybudowano w latach 1755-1760, murowany kościół w stylu barokowym, według projektu architekta królewskiego Jakuba Fontany, w miejsce walącej się drewnianej świątyni poparafialnej. Nowy fundator umieścił na frontowej ścianie wybudowanego kościoła, epitafium dedykacyjne, poświęcone jego żonie Dorocie z Przebendowskich, zmarkej w roku rozpoczęcia budowy $(\dagger 1755)^{35}$.

$\mathrm{W}$ jednym $\mathrm{z}$ warunków fundacji Bieliński zastrzegał dwie wieczyste msze, które miały się odprawiać codziennie za duszę zmarłej żony i o błogosławieństwo Boże dla fundatora ${ }^{36}$. Budowę kościola ukończono w $1760 \mathrm{r}$. W tym samym czasie nawiedziła zakonników klęska pożaru konwentu, który

${ }^{31}$ Wyrażając gotowość wybudowania kościoła, marszałek F. Bieliński zaznaczył, iż nie zobowiązuje się do finansowania wewnętrznego wystroju świątyni. Oto jego słowa: „... deklaruję fundować kościół murowany w Górze i ten prócz ołtarzy, w czasie czterech lat wystawic". - APBK Rkp. W-12, s. 141.

${ }^{32} \mathrm{H}$. W a n i c z k ó w n a, Bieliński Franciszek, [w:] Polski Stownik Biograficzny (dalej: PSB), t. 2:1936, s. 48.

${ }^{33}$ APBK Rkp. W-12, s. 134.

${ }^{34}$ Deklarację fundacji oraz warunki F. Bielińskiego przyjęła kapituła prowincjalna Bernardynów obradująca w Radomiu, w dniu 12 października 1755 r. - APBK Rkp. W-12, s. 141.

${ }^{35}$ W. F. M u r a w i e c OFM, Góra Kalwaria..., s. 72.

${ }^{36}$ APBK Rkp. W-12, s. 141, nr 1. 
spłonął z nieznanych bliżej powodów. Odbudowano go w następnych latach staraniem gwardiana Andrzeja Wilczyńskiego dzięki licznym jałmużnom szlachty i magnatów oraz licznie przybywajacych do Nowej Jerozolimy pielgrzymów. Zadbano o odbudowę konwentu w tym samym stylu barokowym, nadając mu szczególnie piękny charakter we wszystkich szczegółach wykończeniowych. Nie wystarczyło początkowo funduszów na wykończeniu wewnętrznego wystroju budowli, ale dzięki zezwoleniu Stolicy Apostolskiej, by sprzedać na ten cel kawałek gruntu $\mathrm{z}$ nadania biskupa Wierzbowskiego, udało się w końcu sfinalizować „fabricam conventus", jeszcze piękniejszego niż poprzedni $\mathrm{i}^{37}$.

\section{UPOSAŻENIE KONWENTU NOWOJEROZOLIMSKIEGO}

Klasztor nowojerozolimski Ofiarowania NMP został uposażony przez fundatora, który wytyczył aż dwukrotnie - w 1672 i 1679 roku - granice terenu przekazanego na własność Bernardynom. Od strony południowej obszar konwencki graniczył z królewskim pałacem i zwierzyńcem. W południowo-zachodniej części uposażenia znajdował się dość obszerny ogród i sad. Od wschodu naturalną granicę stanowiła Wisła, której oba brzegi oraz wyspa wraz $\mathrm{z}$ budynkiem, na niej wystawionym przez biskupa Wierzbowskiego, należały do Bernardynów. Zgodnie $\mathrm{z}$ wolą fundatora zakonnicy mieli czerpać dochody $\mathrm{z}$ wszystkiego, co znajdowało się na wyznaczonym dla nich terenie, a więc na przykład z promu na Wiśle, wodnego młyna, dwu stawów rybnych oraz części lasu $^{38}$. Od zachodu granica posesji konwenckiej ciągnęła się wzdłuż Warszawskiego Gościńca, a od północy dochodziła do posesji Pijarów ${ }^{39}$.

Poza opisanymi wyżej terenami, biskup fundator zapisał również naszym zakonnikom dwa domy czynszowe na Solcu koło Warszawy w pobliżu Szpitala Francuskiego, a także łąkę na terenie dawnej posiadłości Stanisława Rudzińskiego, kasztelana czerskiego, należącą dawniej do parafii w Górze $\mathrm{n}$. Wisłą ${ }^{40}$. Ponadto w $1686 \mathrm{r}$. fundator ofiarował sumę 10 tysięcy złp. na wymurowanie kościoła i konwentu Bernardynów w Nowej Jerozolimie lokowana na dobrach Stanisława Skarszewskiego, kasztelana wojnickiego ${ }^{41}$. Suma ta została później powiększona przez biskupa do 50 tysięcy złp. ${ }^{42}$

Zgodnie $\mathrm{z}$ tenorem dokumentu fundacyjnego, wpisanego do akt grodzkich w Czersku w 1672 r. konwent w Górze Kalwarii otrzymał szerokie uprawnienia własnościowe łącznie $\mathrm{z}$ władzą patrymonialną nad ludnością wyrobniczą, mieszkającą na terenie fundacji. Wykraczało to zdaniem zakonników

${ }^{37}$ Prowincjał małopolski Andrzej Wilczyński zwrócił się do Stolicy Apostolskiej o tego rodzaju pozwolenie w 1768 r. - APBK Rkp. W-12, s. 149, 151, 152.

${ }^{38}$ Tamże, s. 133.

${ }^{39}$ Tamże.

${ }^{40}$ Tamże, s. 130.

${ }^{41}$ Tamże.

${ }^{42}$ APBK Rkp. M-7: Akta Prowincji Małopolskiej Bernardynów, 1659-1686, s. 335. 
poza przepisy Reguły św. Franciszka, nakazujące ścisłe ubóstwo w kwestii prawa własnościowego. Stąd Bernardyni jak wyżej wspomniano, formalnie zrzekli się prawa własności nad nieruchomościami w Nowej Jerozolimie, oraz władzy patrymonialnej nad ludnościa, na rzecz swojego syndyka apostolskie$\mathrm{go}^{43}$. Pozostawili tylko dla siebie, do bezpośredniego użytkowania ogród i sad, oraz zabezpieczenie funduszów (jałmużn) na budowy, remonty i konserwację kościoła, konwentu i oficyn klasztornych, oraz pewne sumy z dochodów na utrzymanie kapeli dróżkowej, a więc dla tzw. „trębaczy i bębnisty”,44.

Wspomniane wyżej zrzeczenia wobec fundatora i dwóch świadków przyjął syndyk Stanisław Warszycki, kasztelan krakowski. Od tej pory miał on zarządzać majątkiem fundacyjnym, a klasztor miał korzystać z uposażenia, jakby na zasadzie zwyczajnej jałmużny, otrzymywanej w określonych ściśle okolicznościach. Przynajmniej w taki sposób określili swój udział w zapisach fundacyjnych przedstawiciele prawni Bernardynów. Z czasem jednak zapomniano o tych „ściśle określonych okolicznościach", w których miało działać prawo do jałmużny, a zakonnicy korzystali z uposażenia w takim zakresie, jaki im wyznaczył każdorazowo syndyk apostolski. Tę niejasną sytuację prawną usiłował wykorzystać w sto lat po „,zrzeczeniu" miejscowy proboszcz, a zarazem sufragan kijowski bp Franciszek Zembrzuski. Zaskarżył Bernardynów nowojerozolimskich w 1782 r. do Kongregacji Tłumaczy Soboru Trydenckiego, argumentując zakazami Reguły św. Franciszka w sprawie posiadania nieruchomości ${ }^{45}$. Nie wiedział bowiem, iż tego rodzaju sprawy zostały uregulowane prawnie już wcześniej przez papieży w skali całego Zakonu Braci Mniejszych i wszelkie dobra zakonne, przyjmowane z okazji fundacji stanowiły w świetle prawa kościelnego, własność Stolicy Apostolskiej, a zakonnicy mieli być tylko ubogimi ich użytkownikami, na zasadzie jałmużny. Biskup Zembrzuski dazżąc przez swoją akcję do przejęcia uposażeń fundacyjnych ojców Bernardynów w Górze Kalwarii dla swojej parafii, nic nie zyskał, a prowincjał małopolskich Bernardynów, Bonawentura Małecki, wskazując na dokument fundacyjny, wydobyty $\mathrm{z}$ akt grodzkich w Czersku, oraz na zatwierdzenie sejmowe fundacji nowojerozolimskiej z $1673 \mathrm{r}$., zapowiedział odwołanie się do papieża Piusa VI, by na przyszłość zabezpieczyć się przed tego rodzaju atakami ${ }^{46}$.

Dochody roczne konwentu w wieku XVIII wahały się między 6009 złp. w 1720 r., a 6640 złp. w 1788 r. Nawet podczas rządów gwardiana Urbańskiego (1724-1726), na którego niegospodarność wysyłano skargi na kapitułę prowincjalną, dochód roczny nie spadł poniżej $6000 \mathrm{złp}^{47}$ Pewien obraz zamożności konwentu w Nowej Jerozolimie na tle innych klasztorów małopolskich daje też wykaz składek na kapitułę generalną w 1749 r. Składka gwar-

${ }^{43}$ APBK Rkp. W-12: Akta Prowincji Wielkopolskiej ... Bernardynów, XVIII-XIX w., s. $131,137$.

44 Tamże, s. 134, 144, 149.

${ }^{45}$ Tamże, s. 137, 138.

${ }^{46}$ Klasztory bernardyńskie w Polsce..., s. 73.

${ }^{47}$ APBK Rkp. M-10: Akta Prowincji Małopolskiej oo. Bernardynów, 1720-1730, s. 56. 
diana z Góry Kalwarii wynosiła wówczas 4 złp. i była mniejsza od krakowskiej tylko o jeden złoty ${ }^{48}$.

Trwałe źródła dochodów, jakie zapewnił biskup fundator oraz ofiary przybywających do sanktuarium pasyjnego wiernych stanowiły główną podstawę wydatków na konserwację budynków kościelnych i utrzymania konwentu. Wprawdzie zmniejszyła się ilość przekazywanej soli z żupy solnej z 30 na 20 beczek rocznie w drugiej połowie XVIII w., ale znaczny dochód pochodził nadal z przewozu na Wiśle i wynosił 1000 złp. rocznie, z czego połowę przeznaczano na remonty, a połowę na bieżące wydatki. Korzystano też $\mathrm{z}$ opłat czynszowych $\mathrm{z}$ wynajmu domów na Solcu koło Warszawy, młyna wodnego oraz browaru. Wszystkie fundusze czerpane ze stałych źródeł oraz cegielnia i drzewo budowlane $\mathrm{z}$ lasu klasztornego były szczególnie potrzebne w okresie trwania budowy lub konserwacji kościołów i kaplic oraz konwentu. Natomiast zwyczaj dostarczania konwentowi ryb każdego tygodnia przez miejscowych rybaków, był nadal kontynuowany i stanowiły one cenione przez zakonników urozmaicenie codziennego posiłku. Były to zapewne ryby łowione w stawach klasztornych, wspomnianych w dokumencie fundacyjnym, oraz na Wiśle ${ }^{49}$.

GÓRA KALWARIA DRUGIM OŚRODKIEM DUSZPASTERSTWA PIELGRZYMKOWEGO W PROWINCJI MAŁOPOLSKIEJ

Głównym zajęciem Bernardynów w Górze Kalwarii, podobnie jak innych księży zakonnych w ośrodku pielgrzymkowym nowojerozolimskim, była praca duszpasterska wśród napływających pątników oraz pomoc w sąsiednich kościołach parafialnych, a więc spowiedź i głoszenie kazań. Nasilanie się tego rodzaju prac miało miejsce szczególnie w święta Pańskie w Wielkim Poście i zapewne w Adwencie oraz w okresie świąt Matki Bożej, a szczególnie podczas odpustu Ofiarowania Najświętszej Maryi Panny, Jej Narodzenia, Wniebowzięcia i Niepokalanego Poczęcia pod koniec roku. Procesje dróżkowe prowadzone przez Bernardynów odznaczały się dużą frekwencją wiernych i wystawnością. Oprócz kazań wygłaszanych przy kościołach i kaplicach oraz rozmyślań Męki Pańskiej odczytywanych z modlitewników kalwaryjskich, a także śpiewów pasyjnych przygrywała orkiestra, niekiedy w rytmie marszowym. Mieszkali w tym konwencie także księża, którzy już wcześniej uprawiali tego rodzaju duszpasterstwo w Kalwarii Zebrzydowskiej i byli zaopatrzeni w śpiewniki kalwaryjskie, względnie byli nawet ich autorami z myślą o kulcie pasyjnym w całej Prowincji zakonnej, a więc i w Nowej Jerozolimie. Do nich zapewne należał wspomniany już Franciszek Kochanowski, zaliczany w literaturze do autorów piszących modlitewniki na potrzeby Kalwarii Zebrzydowskiej ${ }^{50}$. Był

\footnotetext{
${ }^{48}$ K. K a n t a k, Bernardyni polscy, t. 2, s. 423.

${ }^{49}$ Konwent mógl korzystać z obu brzegów rzeki oraz z wyspy na Wiśle, która stanowila zapewne dogodne miejsce dla rybaków. - APBK Rkp. W-12, s. 134.

${ }^{50}$ H. E. W y c z a w s k i OFM, Kalwaria Zebrzydowska. Historia klasztoru Bernardynów i kalwaryjskich Dróżek, Kalwaria Z. 1987, s.185.
} 
on współautorem drugiego wydania dzieła o Niepokalanym Poczęciu NMP, napisanego przez jego starszego brata Dominika Kochanowskiego, zmarłego w $1666 \mathrm{r}^{51}$ Wśród wpisów dedykacyjnych do drugiego wydania tegoż dzieła (1679) Franciszek zamieścił przysłaną mu łacińską laudację o Niepokalanej NMP, autorstwa sługi Bożego o. Stanisława Papczyńskiego, założyciela Księży Marianów nowojerozolimskich, pt. „Tryumf poczętej bez grzechu pierworodnego, Wielkiej Dziewicy Maryi"s2.

Bernardyni traktowali Nową Jerozolimę jako drugi po Kalwarii Zebrzydowskiej ośrodek duszpasterski w zakonnej Prowincji, o charakterze pielgrzymkowym, wymagający szczególnej troski. Świadczy o tym wysuwanie na przełożonych, zakonników, którzy już wcześniej mieli do czynienia z podobnymi problemami duszpasterskimi. Pierwszy przełożony w Nowej Jerozolimie, o. Kazimierz Domanowski, wyznaczony przez kapitułę zakonną w 1671 r., był wcześniej gwardianem w Kalwarii Zebrzydowskiej (1670), a w dwa lata później awansował na kustosza konwentu krakowskiego św. Bernardyna ze Sieny $(1672)^{53}$. Ponadto ogniwem łączącym obie Kalwarie był również znany nam z załączonych przy końcu artykułu tekstów źródłowych, o. Bonawentura Konopkowicz, gwardian nowojerozolimski z 1679 r. i kaznodzieja generalny w Prowincji Małopolskiej, który w imieniu swoich współbraci występował wobec biskupa Wierzbowskiego wraz z przedstawicielami innych zakonów w Nowej Jerozolimie oraz proboszczami sąsiednich parafii, w sprawie ostatecznego uregulowania praw własnościowych w tym mieście. Pod koniec życia zamieszkał w Kalwarii Zebrzydowskiej ${ }^{54}$.

O ważnej roli duszpasterskiej Nowej Jerozolimy wśród bernardyńskich klasztorów w Polsce świadczy również obsadzanie tutejszej ambony czołowymi kaznodziejami w zakonie. Pracowali nawet dwaj ojcowie, którzy wcześniej byli kaznodziejami w katedrze na Wawelu w Krakowie. Byli to w wieku XVIII: o. Cyprian Idzikowski ( $\uparrow 1744)$ i o. Metody Zeman ( $\dagger 1782)$. O pierwszym z nich wiemy, że był przez wiele lat kaznodzieja katedralnym krakowskim i odznaczał się szczególnie piękną wymową. Obaj zmarli w Nowej Jerozolimie $^{55}$. Ponadto możemy wymienić kilku kaznodziei generalnych zakonu, którzy nauczali $\mathrm{z}$ ambony nowojerozolimskiej, a wcześniej przebywali w największych konwentach zakonnej Prowincji. Byli to między innymi: Franciszek Turobiński ( $\dagger$ 1695), Gabriel Woykowski († 1704), Pacyfik Muszyński

${ }^{51}$ K. E s tr e i c h e r, Bibliografia polska, t. 19. Kraków 1903,s. 358, 359.

${ }^{52}$ Łacińska poezja maryjna o. Stanisława Papczyńskiego pt. „Triumphus sine originali macula conceptae magnae Virginis nova methodo ... adornatae" - opublikowana w dziele o. Dominika Kochanowskiego OFM pt. Novus asserendae Immaculatae ... Deiparae Virginis ... S. Scripturae, Patribus ... insinuatus, ex principiis J.D. Scoti deductus ... per Franciscum Kochanowski multis additionibus auctus, Casimiriae ad Cracoviam 1669, 20-21 nlb.

${ }^{53}$ APBK Rkp. W-12, s. 127, 128.

${ }^{54}$ Zmarł w Kalwarii Zebrzydowskiej w dniu 4 marca 1701 r. w wieku ok. 60 lat. H. E. W y czawski OFM, Kalwaria..., s. 278; APBK Rkp. RGP-k-44: Teki C. Bogdalskiego, k. 76; Rkp. I-b-22, s.67.

${ }^{55}$ APBK Rkp. I-b-22, s. 52 (dotyczy o. Idzikowskiego), s. 55 (dotyczy o. Zemana). 
$(† 1721)$, Dionizy Zalewski $(\dagger 1760)$ i Franciszek Lewitowicz $(\uparrow 1775)^{56}$. Źródła pozwalają nam wymienić tylko tych kaznodziei generalnych, którzy zmarli w Nowej Jerozolimie, a więc siłą rzeczy stanowią oni tylko pewien procent tych wszystkich, którzy pracowali tu nawet przez szereg lat, ale zakończyli życie gdzie indziej. Np. wspomniany już Bonawentura Konopkowicz, były gwardian w Górze Kalwarii i kaznodzieja generalny, zmarł w Kalwarii Zebrzydowskiej w 1701 r.

\section{STUDIUM ZAKONNE TEOLOGII (W 2. POLOWIE XVIII W.)}

W Nowej Jerozolimie mieszkali również lektorzy teologii wykładający w studium krakowskim i w innych studiach Prowincji, a także w tutejszym studium w 2 połowie XVIII w. Po ukończeniu dwuletniego studium filozofii, mieszczącego się przez wiele lat tegoż wieku w Radomiu, klerycy przybywali do Nowej Jerozolimy w celu studiowania teologii. Klasztor ten był im dobrze znany, gdyż wcześniej odbywali w nim nowicjat. Tak było przynajmniej $\mathrm{w}$ drugiej połowie XVIII $\mathrm{w}$. Znamy $\mathrm{z}$ nazwiska jedynie trzech magistrów nowicjatu, którzy zmarli w Górze Kalwarii. Byli to: Krzysztof Iwanicki $(\dagger 1745)^{57}$, Filip Augenszpunger $(\dagger 1784)^{58}$ i Franciszek Hoffman $(\dagger 1799)^{59}$. Ten trzeci łączył niekiedy formowanie nowicjuszy $\mathbf{z}$ urzędem gwardiana konwentu nowojerozolimskiego. Z kolei wśród lektorów teologii zmarłych w Górze Kalwarii należy wymienić: Franciszka Turobińskiego $(\uparrow 1695)^{60}$, Sebastiana Czywankiewicza (ok. 1702) ${ }^{61}$, Michała Podszowskiego $(\dagger 1706)^{62}$, Bernardyna Okoniowskiego $(\dagger 1715)^{63}$ i Ludwika Saulicha $(\dagger 1772)^{64}$. Turobiński był równocześnie kaznodzieją generalnym, a Okoniowski definitorem habitualnym.

Biblioteka studium teologicznego, a zarazem konwencka w Nowej Jerozolimie, której inwentarz pochodzi z 1819 r., liczyła 673 woluminy, przeważnie z zakresu teologii moralnej, życia wewnętrznego i kaznodziejstwa. Było

${ }^{56}$ Wymienieni kaznodzieje generalni pracowali przez pewien czas i zmarli w Górze Kalwarii. Franciszek Turobiński był wcześniej gwardianem w Alwerni k. Krakowa (1686-1689) i w Tykocinie k. Białegostoku (1694); Pacyfik Muszyński, wybrany definitorem (członkiem zarządu zak. Prowincji) w Kalwarii Zebrzydowskiej w 1704 r., w latach następnych (1707-1710) był gwardianem w Radomiu, a następnie w Górze Kalwarii k. Warszawy(1711-1714). Kolejna kapituła zakonna w Kalwarii Zebrzydowskiej (1716) wyznaczyła mu konwent w Nowej Jerozolimie na stałe zamieszkanie - APBK I-b-22: Pia memoria Patrum ac Fratrum ... Provinciae Minoris Poloniae, s. 265 (dotyczy Turobińskiego), s. 295 (Woykowski), s. 66 (Muszyński), s. 106 (Zalewski), s. 290 (Lewitowicz).

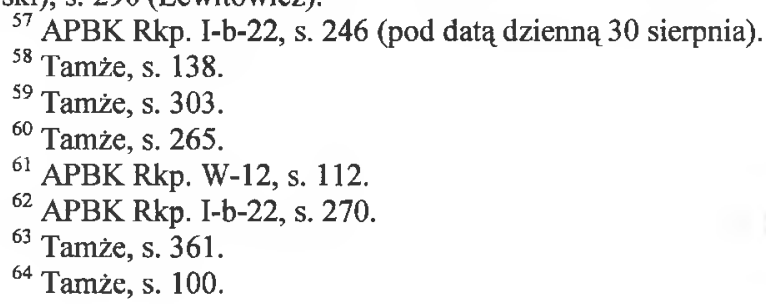


w niej też kilka podręczników z pozostałych dyscyplin teologicznych, m.in. $\mathrm{z}$ dogmaty $\mathrm{ki}^{65}$.

Po podziale Prowincji Małopolskiej, nazywanej dotychczas małopolską lub małopolsko-litewska, dokonanym w 1731 r., na dwie osobne prowincje małopolską i litewską, klasztor w Górze Kalwarii, należący do Prowincji Małopolskiej, podniesiono do rangi konwentu kustodialnego ${ }^{66} \mathrm{w}$ miejsce Wilna i kustodii wileńskiej, która znalazła się w Prowincji Litewskiej. Wyróżnienie to, poza tytułem konwentu kustodialnego i honorowym tytulem gwardiana Nowej Jerozolimy zwanego odtąd kustoszem - nie miało charakteru jurysdykcyjnego i nie dawało jakichkolwiek przywilejów. Z kolei w $1810 \mathrm{r}$. konwent nowojerozolimski przydzielono do zakonnej Prowincji Wielkopolskiej, już wówczas znacznie uszczuplonej. Należał wraz z klasztorem czerniakowskim koło Warszawy, do głównych konwentów bernardyńskich na terenie Królestwa Polskiego Kongresowego ${ }^{67}$.

Wśród zakonników bernardyńskich mieszkających w Górze Kalwarii wyróżniło się przynajmniej pięciu jako odznaczający się stosunkowo wysokim poziomem życia wewnętrznego. Byli to m.in. trzej wikarzy konwentu: Augustyn Podkowa (Podkovius) zmarły w 1692 r., Ludwik Bykowski († 1717) i Innocenty Au (sic!). Pierwszego z nich, Augustyna źródła określają jako najgorliwszego w życiu zakonnym (,religiosissimus"), o. Lúdwika z kolei, jako przykładnego w miłości („,caritate exemplar.[issimus]”), zaś o. Innocentego jako zakonnika przestrzegającego ściśle Regułę św. Franciszka („verae observ.[antiae]") ${ }^{68}$. Czwartym kandydatem na ołtarze był pustelnik Stanisław Starosielski, tercjarz oblat konwentu w Górze Kalwarii. Jego męczeńska śmierć była prawdziwym wstrząsem dla klasztoru nowojerozolimskiego i wiernych w połowie XVIII w. Prowadził on życie pustelnicze w lesie w pobliżu wsi Konary nad Wisłą nie daleko Góry Kalwarii, i w r. 1745 został zamordowany przez bandytów, szukających złota w jego pustelni. Pochowano go w krypcie klasztornej w Nowej Jerozolimie ${ }^{69}$. Do świątobliwych braci zaliczano również kwestarza, brata Romana Zguzikiewicza, gorliwego zakonnika (,religiosissimus"), przykładnego w wykonywaniu swojej pracy kwestarskiej. Zmarł w konwencie w Górze Kalwarii w 1750 r. ${ }^{70}$

${ }^{65}$ Inwentarz biblioteki konwenckiej i studyjnej z Góry Kalwarii, opracowany na stosunkowo niskim poziomie (jedynie tytuły, bez autorów i adresów wydawniczych) znạjuje się w APBK Rkp. W-12, s. 157-167.

${ }^{66}$ Wyniesienie konwentu w Górze Kalwarii do rangi kustodialnego miało miejsce podczas obrad kapituły prowincjalnej w Tarnowie w 1731 r. - K. K a n t a k, Bernardyni..., t. 2, s. 413.

${ }^{67}$ Tamże, s. 523.

${ }^{68}$ APBK Rkp. I-b-22, s.71 (o. Podkowa), s. 157 (o. Bykowki), s. 172 (o.Au).

${ }^{69}$ APBK Rkp. W-12, s. 126.

${ }^{70}$ APBK Rkp. I-b-22, s. 68. 
Należy też wspomnieć o ofiarach epidemii, jaka panowała w Nowej Jerozolimie podczas wojny północnej, w $1708 \mathrm{r}$. Zmarli wówczas trzej zakonnicy, dwaj księża i jeden kleryk, diakon. Byli to: gwardian Andrzej Molecki, kaznodzieja Józef Kowalkiewicz i diakon Hieronim Tyniecki ${ }^{71}$. Epidemia zagroziła konwentowi już na początku sierpnia 1708 r., kiedy zmarł najpierw o. Molecki, ale jeszcze $\mathrm{z}$ końcem roku, w grudniu pochłonęła dwie kolejne ofiary - o. Kowalkiewicza i br. Tynieckiego. Pochowano ich w krypcie konwenckiej.

W omawianym klasztorze mieszkało zazwyczaj od kilku do kilkunastu zakonników. Na początku XIX w. było ich dziesięciu, ale już w 1833 r., tylko sześciu, mianowicie czterech księży i dwóch braci. W 1856 r. było siedmiu, a w 1860 znów dziesięciu zakonników (ośmiu księży i dwóch braci) ${ }^{72}$. W 1863 roku podczas powstania styczniowego klasztor nowojerozolimski stanowił kwaterę dla powstańców, co było zasadnicza przyczyną późniejszych represji i ostatecznej likwidacji przez władze carskie ${ }^{73}$. Wśród represjonowanych Bernardynów nowojerozolimskich po stłumieniu powstania znalazł się m.in. gwardian konwentu Jozafat Ludwicki, którego osadzono w Cytadeli warszawskiej na dwa lata. Kleryk Bartłomiej Rybus ${ }^{74}$, za udział w powstaniu, został zesłany w głąb Rosji. Z kolei o. Walenty Tercyak, miejscowy kaznodzieja został oskarżony o publiczne popieranie powstańców, w kazaniach patriotycznych. Natomiast 0 . Mariana Józefa Wierzbickiego z konwentu w Górze Kalwarii władze oskarżyły za udział $w$ manifestacjach przedpowstaniowych, w 1861 i 1862 r. Zarówno jego, jak i o. Tercyaka władze potraktowały stosunkowo najłagodniej, gdyż tylko na policyjny nadzór ${ }^{75}$.

Podczas ogólnej akcji kasowania klasztorów bernardyńskich w 1864 r., po upadku powstania styczniowego, na razie oszczędzono konwent w Nowej Jerozolimie jako ponadetatowy ${ }^{76}$. Został zlikwidowany dopiero w roku 1873. Liczył wtedy jedenastu zakonników ${ }^{77}$. Kościół Ofiarowania Najświętszej Maryi Panny pozostał nadal czynny, a w $1881 \mathrm{r}$. zamieniono go na parafialny. Ostatecznie w 1952 r. w konwencie pobernardyńskim w Górze Kalwarii osiedlili się ojcowie Marianie.

${ }^{71}$ APBK Rkp. I-b-22, s. 223 (dotyczy o. Meleckiego), s. 364 (dotyczy o. Kowalkiewicza i br. Tynieckiego).

${ }^{72}$ E. J a b ł oń s k a - D e p t u ł a, J. G a w r y s i a k ow a, Materiały do zaangażowania patriotycznego zakonów męskich w Królestwie Polskim w latach 1861-1864, [w:] Materiały do historii zgromadzen zakonnych na ziemiach polskich $w X I X i$ poczatkach XX $w$, pod red. L. Bieńskowskiego i J. Kłoczowskiego i in. Lublin 1976, s. 98.

${ }^{73}$ K. Kantak, Bernardyni..., t. 2, s. 544; W. F. Murawi e c OFM, Góra Kalwaria..., s. 74.

${ }^{74}$ E. J a błońska-Deptuła, J. Gawrysiakowa, Materiały do zaangażowania patriotycznego..., s. 110, $\mathrm{nr} 77$.

75 Tamże, s. 158 nr 15; W. F. M u rawie c OFM, Bernardyni warszawscy, 1454-1864, Kraków 1973, s. 185.

${ }^{76}$ Władze zaborcze uznały cztery klasztory Prowincji Wielkopolskiej, za etatowe. Miano w nich zgrupować zakonników skazanych na wymarcie. Ponadto cztery inne konwenty: w Górze Kalwarii Ratowie, Strzegocinie i Tykocinie - jako ponadetatowe, - H. E. W y c z a w s k i OFM, Bernardyni polscy, t. 3, Kalwaria Z. 1992, s. 173.

${ }^{77}$ K. K a n t a k, Bernardyni..., t. 2, s. 547. 


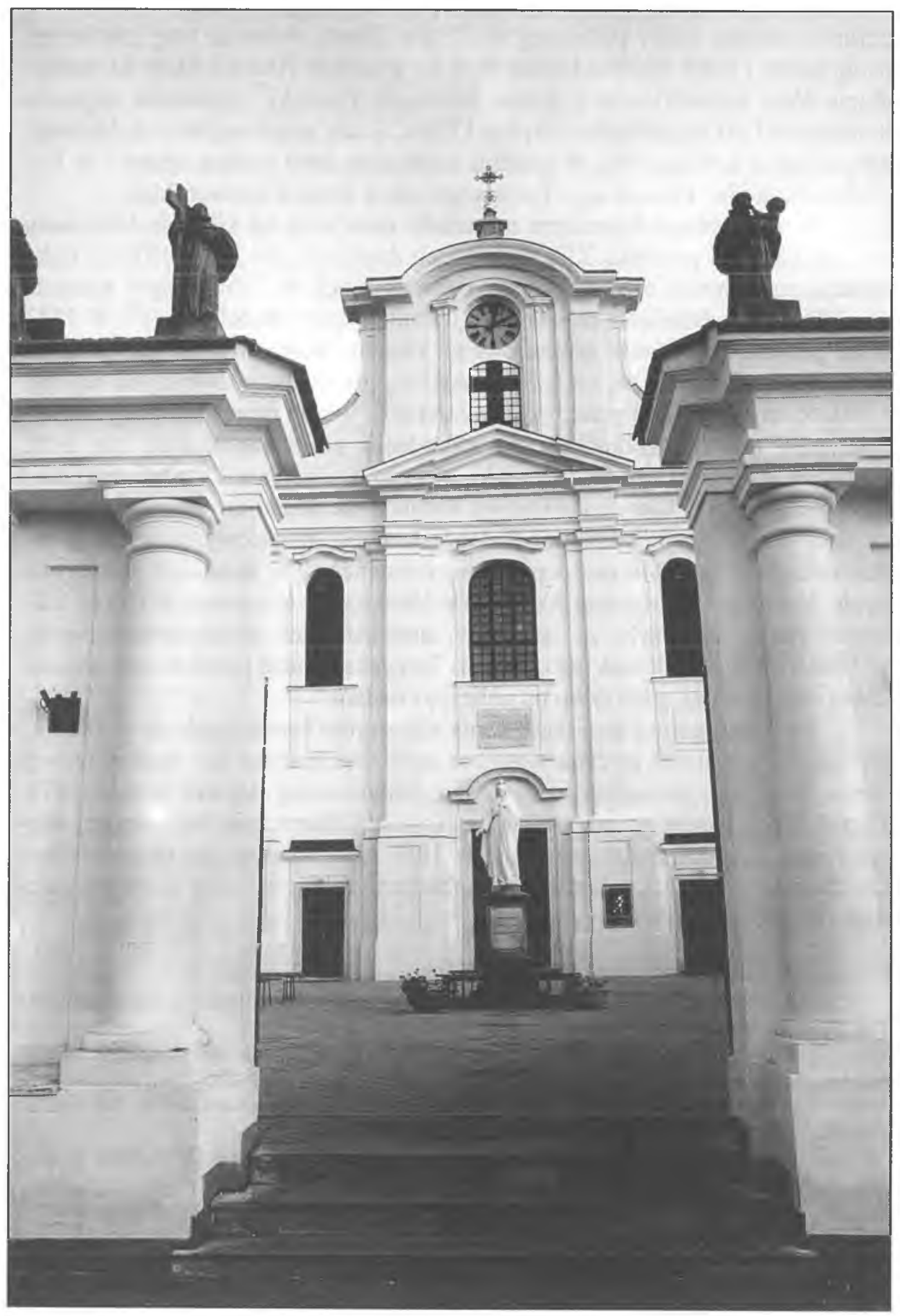

1. Fronton kościoła pobernardyńskiego w Górze Kalwarii (fot. P. Chmielowski). 


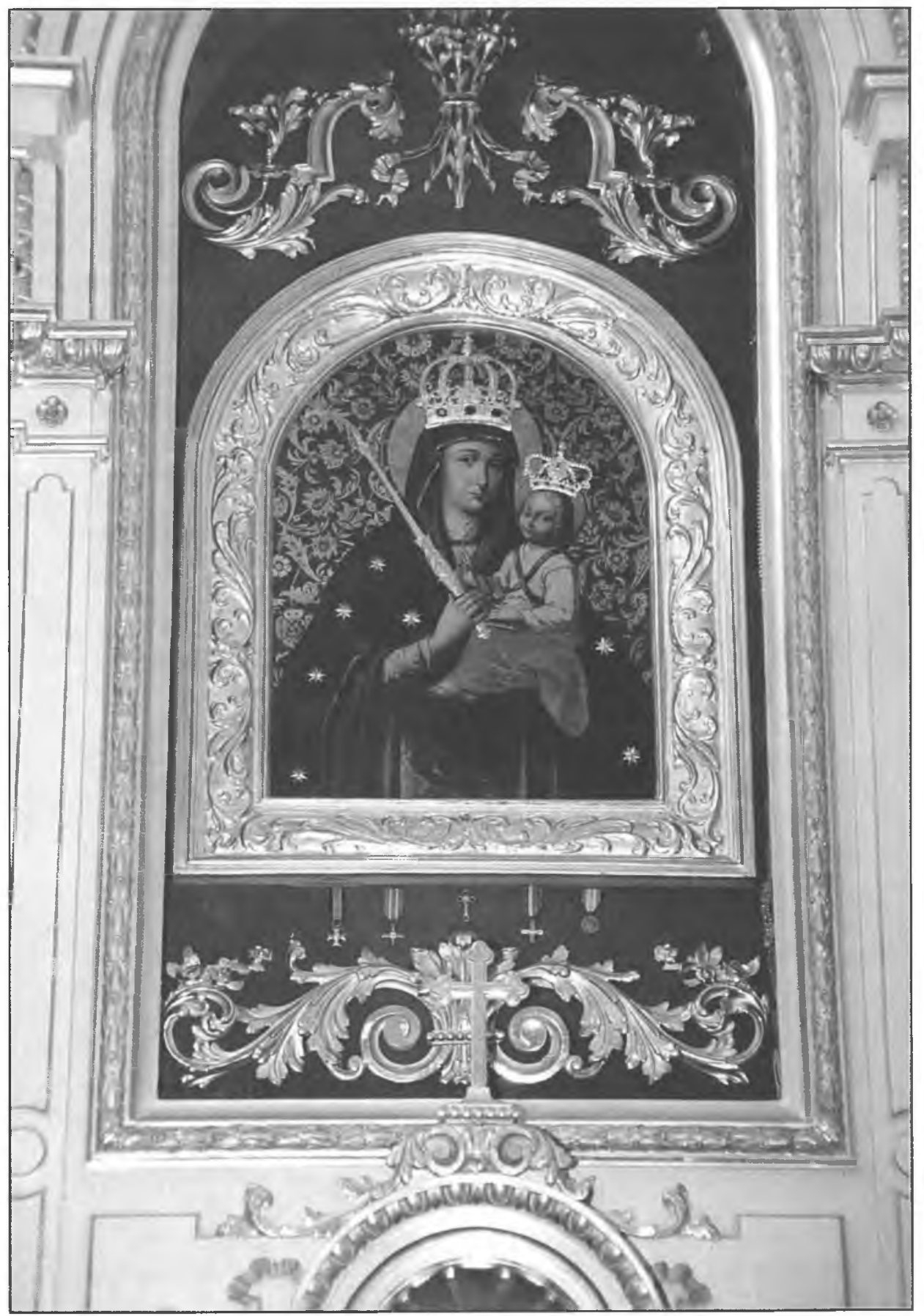

2. Obraz Matki Bożej Górskiej w kościele pobernardyńskim w Górze Kalwarii (fot. P. Chmielowski). 


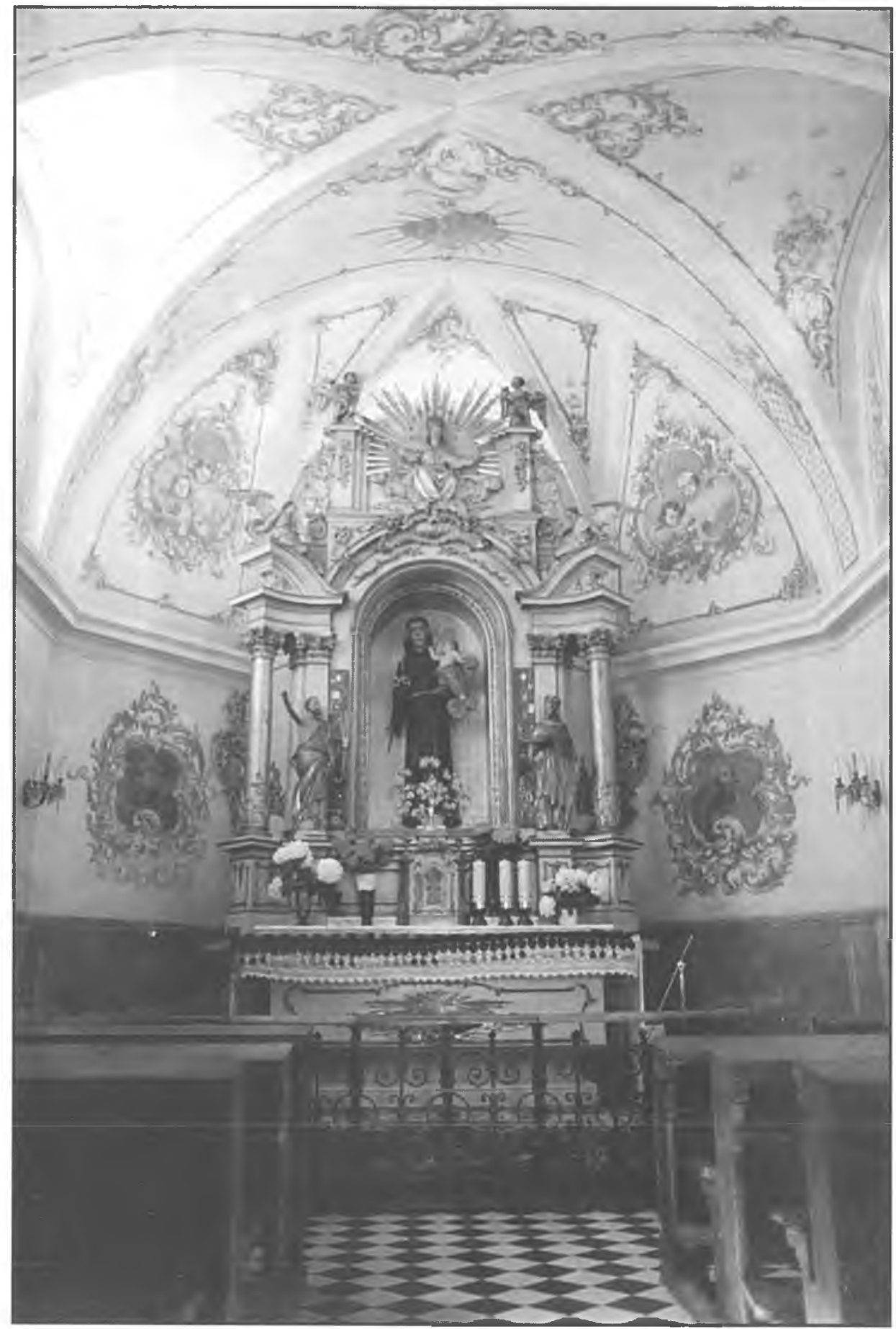

3. Wnętrze kaplicy św. Antoniego z Padwy w Górze Kalwarii n. Wisłą (fot. P. Chmielowski). 


\section{EDYCJA ŹRÓDŁA}

\section{Opis fundacji konwentu oo. Bernardynów w Nowej Jerozolimie (s. 111:) Orig.: Fundatio seu erectio... - Archiwum Prow. Bern. w Krakowie Rkp. W-12, s. 111-112}

(s. 112:) Konwent Nowej Jerozolimy czyli Górski ufundowany pod tytułem i patronatem Ofiarowania Najświętszej Maryi Panny przez Stefana z Wielkiego Chrząstowa Wierzbowskiego, z łaski Bożej i Stolicy Apostolskiej biskupa poznańskiego, ordynariusza miejsca i w roku Pańskim 1670 objęty, a budynek klasztorny, $\mathrm{z}$ cegły od fundamentów rozpoczęty przez niego i po latach przez innych prześwietnych dobrodziejów, choć jeszcze nie do końca, został wybudowany. Kościół tego konwentu wzniesiony przez tegoż Fundatora z drzewa, ze względu na upływ czasu i nieszczęśliwy przypadek ${ }^{\mathfrak{a}}$ (pożaru), przez silne wiatry doprowadzony do ruiny. Kościół posiada trzy ołtarze: ołtarz wielki Ofiarowania Najświętszej Maryi Panny, drugi - Matki Bożej Bolesnej, słynący cudami, i trzeci - św. Franciszka z Asyżu, którym się opiekuje bractwo pod wezwaniem tegoż świętego (Ojca), które jako jedyne istnieje przy tym kościele ${ }^{78}$. Jest również kaplica, po lewej stronie (wchodząc do kościoła), pod wezwaniem św. Waleriana Męczennika ${ }^{79}$, zbudowana $\mathrm{z}$ materiału drewnianego. W niej leży ciało tegoż Męczennika w marmurowym grobowcub Konwent szczyci się również posiadaniem cząsteczki Drzewa Życia (Krzyża Chrystusowego), umieszczonego w srebrnym krzyżu (relikwiarzu). Ofiarował je zakonowi prześwietny Fundator, jako dowód swej łaskawości i pobożności. Konwent ma (również inną) kaplicę, św. Antoniego Padewskiego, należącą do tegoż kościoła, stojąca przy Wiśle, nie daleko od konwentu, zbudowaną z cegły przez tegoż prześwietnego Fundatora. Ozdabia ją drewniana figura tego świętego, słynąca licznymi cudami. Najprzewielebniejszy Fundator uczynił osobną fundację mszalną, $\mathrm{z}$ krótkimi rozważaniami, realizowaną we wszystkie piątki roku, w kaplicy Piłata, nie należącej do naszego kościoła ${ }^{80}$.

Utrzymanie tutejszej świętej wspólnoty opiera się na „czystej" jałmużnie.

(Podpisy pod tekstem:)

(Nowa Jerozolima) 27 stycznia
A.D. 1702
Ita est
(Podpisani):

${ }^{78}$ Chodzi tu o bractwo Paskowe św. Franciszka z Asyżu (Societas Chordigerorum), działające przy większości kościołów bernardyńskich w Polsce.

${ }^{79}$ Sw. Walerian męczennik rzymski oddał życie za wiarę około 230 r. po Chrystusie, za panowania cesarza Aleksandra Sewera. Martyrologium rzymskie wspomina go pod dniem 14 kwietnia. - Martyrologium rzymskie. Przeł. i oprac. Piotr T u rb a k SJ. Kraków 1967, s. 112.

${ }^{80}$ Kaplica Piłata w Górze Kalwarii zastała wyróżniona osobną fundacją mszalnq dlatego tu właśnie przeniesiono szczątki fundatora w 1791 r. - J. Ptak, M. Wr ze s z c z, Góra Kalwaria, [w:] Encyklopedia Katolicka, t. 5, kol. 1371. 
o. Pacyfik Muszyński
gwardian konwentu

o. Sebastian Czywankiewicz (?)

lektor teologii moralnej

(pieczęć papierowa podłużna;

- pośrodku: wizerunek Ofiarowania NMP;

- napis w otoku nieczytelny) o. Wincenty Żabczyński ${ }^{82}$ wikary konwentu

o. Antoni Rozworowicz ${ }^{84}$

kaznodzieja miejscowy

\section{(Pisma związane z realizacją fundacji Nowej Jerozolimy czyli Góry Kalwarii)}

W Imię Pańskie. Amen. Stefan z Wielkiego Chrzastowa Wierzbowski za łaskę Bożą i Stolicy Apostolskiej Biskup Poznański, ordynariusz miejsca i delegat komisarz wykonawczy pism Kongregacji Kard. Interpretatorów Soboru Trydenckiego.

\section{(Przeklad skrócony)}

Orig.: In Nomine Domini. Amen. Stephanus de Magna Chrząstow Wierzbowski ... (Archiwum Prow. Bern, w Krakowie Rkp. W-12, s. 113, 127 nn.)

Wszem wobec i każdemu z osobna niniejsze pismo na wiecznej rzeczy pamiątke ... (etc) zebranym na Trybunale - ojcu zakonnemu Bonawenturze Konopkowiczowi ${ }^{85}$, kaznodziei generalnemu zakonu św. Franciszka obserwantów z Prowincji Małopolskiej, gwardianowi nowojerozolimskiemu występującemu w imieniu tegoż zakonu i konwentu w terminie dzisiejszym, na wezwanie pismem pozywającym ... podanym do publicznej wiadomości z ambony kościoła oo. Bernardynów rzeczonego konwentu nowojerozolimskiego, przez wielebnego Jana Kazimierza Kampowskiego kapłana ... podczas oktawy Bożego Ciała ${ }^{86}$; wobec zebranego ludu ... oraz rozesłanym w kopiach w drugim dniu miesiąca bieżącego i roku, wielebnym ojcom zakonnym, Andrzejowi Godkowskiemu, dziekanowi i proboszczowi nowojerozolimskiemu, probosz-

${ }^{81}$ Zob. przyp. 57 - w 1705 r. był kaznodzieją w Radomiu - APBK Rkp. M-8: Akta Prowincji Małopolskiej Bernardynów, 1686-1709, s. 420.

${ }^{82} \mathrm{~W}$ dwa lata później był wikarym konwentu w Opatowie.

${ }^{83}$ Zob, przyp. 62.

${ }^{84}$ W 1705 r. byl kaznodzieja w Kalwarii Zebrzydowskiej. - APBK Rkp. M-8, s. 420.

${ }^{85}$ Podczas obrad kapituły prowincjalnej w Wilnie, w 1677 r. został wyróżniony tytułem kaznodziei generalnego, a w 1679 r. został mianowany gwardianem w Nowej Jerozolimie. APBK Rkp. M-7, s. 273.

${ }^{86}$ Ogłoszenie z ambony kościoła Ofiarowania NMP w Nowej Jerozolimie dekretu Kongregacji rzymskiej miało miejsce w roku wydania tegoż dekretu, w niedzielę, w dniu 7 czerwca 1676 r. Święto Bożego Ciała wypadało wówczas w dniu 4 czerwca - por. Chronologia polska, pod red. B. Włodarskiego. Warszawa 1957, s. 377, tab. 15. 
czom sąsiednich parafii: Jerzemu Sadkowskiemu z Sobikowa i Wojciechowi Włodkowskiemu z Czerska, oraz przeorowi nowojerozolimskiemu zakonu św. Dominika z kongregacji św. Ludwika Bertranda (Obserwantów) ${ }^{87}$, jak również wicerektorowi ojców Pijarów z tutejszego kolegium, dyskretowi Piotrowi Stikiewiczowi ${ }^{88}$, rektorowi szkoły w Sobikowie ... (w sprawach dotyczących) realizacji dokumentów: oficjalnej fundacji, wprowadzenia w prawne posiadanie, deklaracji wydanej przez Kongregację Kard. Interpretatorów Soboru Trydenckiego (z 29 lutego 1676 r.) w sprawie przeniesienia dawnego tytułu kościoła parafialnego, który to kościół i miejsce zostały dane już wcześniej ojcom Bernardynom z Prowincji Małopolskiej na ich kościół zakonny i konwent (wraz ze swymi przyległościami wymienionymi w dokumencie fundacyjnym) oraz w sprawie ewentualnych roszczeń do tego miejsca ze strony Księży Kongregacji św. Filipa Nereusza ${ }^{89}$, mieszkających przy kościele parafialnym św. Krzyża na Górze Ukrzyżowania (Kalwarii) w Nowej Jerozolimie ...

(s. 128:) nakazujemy wam wszystkim, wyżej wymienionym, pod sankcją ekskomuniki i na mocy świętego posłuszeństwa, byście stawili się na usilną prośbę ojca Bonawentury Konopkowicza ... gwardiana konwentu nowojerozolimskiego ... My również wzywamy was, byście stawili się przed nami i naszym sądem apostolskim w Nowej Jerozolimie, w miejscu zwyczajnym naszej rezydencji ... w dniu ósmym od ogłoszenia tejże cytacji ... osobiście i pełnoprawnie.

(s. 129:) Dekret Kongregacji Kard. Interpretatorów Soboru Trydenckiego z $1676 \mathrm{r}{ }^{90}$ dał przyzwolenie na przeniesienie tytułu kościoła parafialnego w Górze Kalwarii z dotychczasowego kościoła pod wezwaniem Wniebowzięcia Najśw. Maryi Panny na kościół św. Krzyża, nowowybudowany na wzgórzu Ukrzyżowania - nakazywał też ostateczne rozgraniczenie uposażeń fundacyjnych braci mniejszych Bernardynów przy dotychczasowym kościele Wniebowzięcia Najśw. Maryi Panny (później zmienionym na „Ofiarowania NMP”) oraz oo. Filipinów przy kościele św. Krzyża. Ponadto w związku z wprowadzeniem w życie tegoż dekretu, zeznawali (wezwani wyżej wspomnianym pozwem): kierownik szkoły parafialnej z Sobikowa (k. Grójca), Piotr Skibiewicz $^{91}$ proboszcz parafii Góra Kalwaria, Andrzej Gotkowski, przełożony konwentu Dominikanów Obserwantów w Nowej Jerozolimie oraz wicerektor kolegium Pijarów w Górze Kalwarii, jak również Jerzy Sadkowski proboszcz z Sobikowa i Wojciech Włodkowski proboszcz w Czersku ....

Dan w Nowej Jerozolimie w dniu 17 miesiaca maja 1679 r.

(miejsce na pieczęć) (podpisany:)

Stephanus Wierzbowski eppus Posn.

${ }^{87}$ APBK Rkp. W-12, s. 129.

${ }^{88} \mathrm{Na}$ innym miejscu tegoż rękopisu (s. 129) mamy inną wersję tego nazwiska: „Ego Petrus Skibiewicz rector scholae parochialis ecclesiae Sobicoviensis..."-APBK Rkp. W-12, s. 129.

${ }^{89}$ Zob. przypisy: 8, 11, 12.

${ }^{90} \mathrm{~W}$ publikowanym rękopisie jest omyłkowo: 1679 r. - APBK Rkp W-12, s. 129.

${ }^{91}$ W rękopisie sygn. W-12 na s. 127 mamy inną wersję tegoż nazwiska - jako „Piotr Stikiewicz". 


\section{Oblata fundacji w Grodzie starościńskim w Czersku:}

Działo się w grodzie czerskim w środę po niedzieli „Misericordiae" ${ }^{\text {,92 }}$ przed urzędem grodzkim starostwa czerskiego. Zjawił się osobiście Przewiel. Stefan z Wielkiego Chrząstowa Wierzbowski ... biskup poznański, dziedziczny właściciel dóbr Góry czyli Nowej Jerozolimy, usytuowanych w ziemi i powiecie (obwodzie) czerskim - w pełni sił duchowych i fizycznych, który na mocy swojej władzy zwyczajnej ... na nowo stwierdził dobrowolnie, jawnie i szczerze, że kierując się gorliwością o chwałe Bożą oraz pobudzony pobożnym afektem względem ukrzyżowanego Zbawiciela w tym, że w tejże swojej fundacji w Górze, zatroszczył się o wzniesienie Nowej Jerozolimy, jakby $\mathrm{z}$ nowego fundamentu, dla uczczenia pamięci gorzkiej męki i śmierci Jezusa Chrystusa Zbawiciela Naszego, budując od podstaw, z wszystkimi kaplicami, przy trakcie drogi męki Pańskiej. - Umieścił tu zakonników z Zakonu Braci Mniejszych regularnej obserwancji ${ }^{93}$, (czyli z rodziny Patriarchy św. Franciszka, mianowicie Bernardynów Prowincji Małopolskiej) w tymże miejscu czyli kościele dawniej parafialnym pod tytułem Wniebowzięcia Najśw. Dziewicy Maryi i ufundował ,de nova radice"94.

Ich konwentowi wystawionemu w krótkim czasie, oraz całej Prowincji zakonnej Małopolskiej przeznaczył wspomniany kościół parafialny górski oraz przekazał ze wspomnianych dóbr swoich dziedzicznych, prawem wieczystej fundacji, cząstkę dla zabezpieczenia zakonu, na ręce ich generalnego syndy$\mathrm{ka}^{95}$. Także dla służby Bożej w tym świętym miejscu, gdzie rozwija się chwała Boża i z dnia na dzień wśród wiernych, licznie napływających, coraz bardziej wzmaga się pobożność. Fundator przypisał i ustanowił taki oto sposób realizowania (użytkowania) fundacyjnego zamysłu: Najpierw zaczynając od rzeki Wisły, tam gdzie stoi browar i granicą południową idąc w kierunku wzgórza, do spichlerza i głównej części folwarku, przy którym stoi kaplica na grobli, czyli „Na Szancu”, murowana wraz ze wspomnianymi budowlami, to jest browarem poniżej i malutkim domkiem ${ }^{\mathrm{d}}$ powyżej, czyli na wzgórzu, przy którym biegnie prosta linia aż do ogrodzenia, czyli „,ku parkanowi”e, za którym nowe budynki wraz $\mathrm{z}$ folwarkiem rozmieszczono dla wygody ojców i braci. Przy browarze znajdują się dwa stawy rybne i źródło', nad którym wznosi się kaplica. Wszystko to ma należeć do ojców Bernardynów. Dalej, a więc ,w tyle"g folwarku rozciaga się ogród, od ogrodzenia folwarku do ogrodzenia wzdłuż drogi publicznej, między domem a obora, aż do ogrodzenia ciagnącego się od spichlerza, gdzie linia graniczna wychodzi poza powierzchnię kwadratu.

${ }^{92}$ Środa po niedzieli „Misericirdiae” w 1672 r. wypadała w dniu 4 maja. - Chronologia polska.., s. 401, nr 27.

${ }_{93}$ Zakon Braci Mniejszych regularnej Obserwancji powstał z podziału jednolitego Zakonu Braci Mniejszych św. Franciszka, w roku 1517. W Polsce zapoczątkowany przez Św. Jana Kapistrana w 1453 r. otrzymał nazwę popularną „Bernardyni”.

${ }_{94}^{94}$ De nova radice - z nowego korzenia (fundamentu).

${ }^{95}$ Syndykiem czyli administratorem uposażeń fundacyjnych Prowincji Małopolskiej był wówczas Stanisław Warszycki kasztelan krakowski (zm. 1680). 
(s. 130:) Do tegoż konwentu będzie należał także teren od prostej grani-

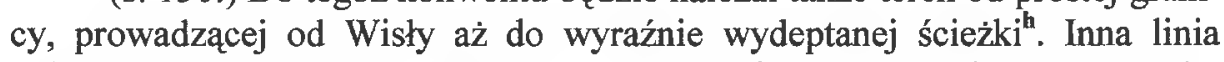
obiegająca teren w kształcie kwadratu zaczyna się od wspomnianego początku ogrodu, inaczej „od rogu”i i ciagnie się prosto aż do początku folwarku przy grobli, czyli „wedle Szanca", na którym stoją dwie murowane kaplice. I tak idąc wydeptaną ścieżką wzdłuż granicy zachodniej (fundacji), przy wałach cmentarnych rozciaga się pas drogi publicznej ze stojącą po lewej stronie karczma, a po prawej domem i stawem, leżącymi na terenie konwenckim. Jednak prawa do użytkowania stawu konwent nie będzie mógł miastu ograniczać. Dalej aż do dwu wielkich dębów granicznych czyli wydeptaną ścieżką która oddziela tereny Lubkowa ${ }^{96}$ od Góry, dalej ciągnie się pole na wzgórzu i wraz z dolną czéścią wzgórza czyli z „Podgórzem”, aż do samej Wisły, idąc linią północną do samej rzeki. I na tym Podgórzu stoją domy, a dawniej stała tu rezydencja czyli dwór właścicieli Górskich ${ }^{97}$. Wszystko to będzie należało do konwentu, albo raczej do dyspozycji syndyka generalnego tychże ojców Prowincji Małopolskiej. I ktokolwiek zechciałby wybudować na terenie tej fundacji jakiś dom, będzie on należał do dyspozycji tegoż syndyka. W ten sposób ujmując całą fundację - czwarta linia graniczna prowadzi w kierunku wschodnim, Wisłą aż do wspomnianego wyżej browaru, przy którym znajduje się przeprawa (prom) i młyn wodny, które mają na wieczne czasy służyć konwentowi. Jednak brzeg wiślany w przypadku zaistniałej konieczności ma służyć każdemu i konwent nie może tego prawa odmówić. Ponadto, ponieważ tu jest pomieszczenie żupy solnej, z okazji więc składowania soli na tym miejscu, corocznie 20 beczek soli przeznaczył pobożny fundator dla tegoż konwentu, a także z obrzeża rzeki obrośniętego jeżynami, nakazał pewną część wydzielić dla tegoż klasztoru i obiecał tę część oddzielić kopczykami granicznymi. Na wymurowanie kościoła oraz klasztoru zapisał 10 tysięcy złotych polskich, które złożył u Stanisława Skarszewskiego ${ }^{98}$, kasztelana wojnickiego. Dom na Solcu koło Warszawy, stojący na przeciw szpitala francuskiego oraz łąkę należące od najdawniejszych czasów do kościoła parafialnego w Górze ... temuż konwentowi przeznaczył na wieczne czasy ${ }^{99}$. Ze względu na te wszystkie, wcześniej zapowiedziane i wymienione zapisy konwent nie został obciążony żadnymi zobowiązaniami, jedynie tylko, by zgodnie ze swym powołaniem modlił się do Boga Najwyższego w Trójcy, za dobrodziejów tego miejsca, żywych i umarłych oraz pamiętał o duszach w czyśćcu, nie mających z nikąd

${ }^{96}$ Lubków - wieś w parafii Góra Kalwaria.

${ }^{97}$ Biskup poznański Stefan Wierzbowski wykupił wieś Górę i Wólkę Górską w $1666 \mathrm{r}$. od Mikołaja i Konstantego Górskich h. Doliwa. - Zob. przyp. nr 3; J. P t a k, M. W r z e s z c z, Góra Kalwaria, [w:] Encyklopedia Katolicka, t. 5, kol. 1370.

98 Kasztelan wojnicki Stanisław Skarszewski h. Leszczyc był żonaty z Katarzyna Wierzbowska, wdową po bracie biskupa Stefana Wierzbowskiego, Hieronimie - M. N a g i e 1 s k i, Skarszewski Stanistaw (1602-1685), [w:] Polski Stownik Biograficzny, t. 38, s. 49.

${ }^{99}$ Uposażenia należące dawniej do parafii w Górze Kalwarii, a teraz przyznane Bernardynom, stały sie przedmiotem sporu w sto lat później, gdy prepozyt tej parafii biskup sufragan kijowski Franciszek Zembrzuski w 1782 r. zaskarżył prawa Bernardynów do nadań uposażeniowych biskupa Stefana Wierzbowskiego w Górze Kalwarii. - Por. przyp. 45. 
pomocy. Żeby obchodził wraz z ludem Drogi krwawe Ukrzyżowanego Zbawiciela. Odnosi się to również do ojców Zakonu Kaznodziejów św. Dominika ściślejszej reguły, mieszkających przy Domku Maryi Dziewicy oraz do innych kapłanów ${ }^{100}$, a więc duchowieństwa mieszkającego na wzgórzu Ukrzyżowania Chrystusa Pana, gdyby jakiś napływ ludzi, czyli kompania przybyła do któregoś $\mathrm{z}$ ich kościołów i poprosiła o przewodnika. $\mathrm{Z}$ tą kompanią wychodząc ze swojego kościoła, mają obowiązek obejść Drogi Pana ${ }^{101}$. Do odnawiania kaplic wymurowanych na Szańcu, a także kościoła i klasztoru są zobowiązani wspomniani ojcowie Bernardyni. I mają oni wypełnić intencje prześwietnego dobrodzieja i fundatora, a najbardziej ojcowie Jacek Burkwicz ${ }^{102}$ prowincjał i Franciszek Dzielowski ${ }^{103}$ sekretarz tejże zakonnej Prowincji, którzy w imieniu tej całej Prowincji przyjęli wszystkie wyżej wymienione warunki fundacji, pod którymi Najprzewielebniejszy Dobrodziej udzielił i zgodził się na rzeczywiste wprowadzenie tychże ojców oraz ich aktualne i spokojne objęcie fundacji w posiadanie, za pośrednictwem najwyższych urzędów krajowych, w obecności dwóch świadków ze szlachty, a więc oficjalnie i pełnoprawnie. Wszystko to zgodnie z prawem fundator nadaje i przekazuje. Nadane zaś i przyjęte zasady fundacji w żaden sposób ani on sam ani jego podwładni nie będą mogli unieważnić ani w czymkolwiek przeszkodzić w ich realizowaniu. Sam fundator poddaje się wraz ze swymi spokrewnionymi spadkobiercami wszystkim zobowiązaniom prawnym i pozaprawnym oraz zobowiązuje się i wszystkich swoich spadkobierców, by w każdym sądzie i urzędzie państwowym, jak tylko zaistnieje taka potrzeba, mieli staranie, bronili, popierali, wstawiali się (w razie zaistnienia jakiejkolwiek trudności), i to w sposób zdecydowany, bez jakichkolwiek zmian fundacji na przyszłość. Fundację dla wspomnianych ojców Bernardynów, całej Prowincji Małopolskiej fundator ustanawia i na wieczne czasy z pomocą łaski Boga wyraża wolę, by była nienaruszona. Czyni to za

${ }^{100}$ W 1677 r. Dominikanie Obserwanci mieszkali początkowo na Górze Syjon przy Domku Maryi od ok. 1671 r. do 1677 r. Ustapili tę placówkę siostrom Dominikankom z Kamieńca Podolskiego, a sami objęli kościół Wniebowzięcia NMP pozostający jeszcze w budowie oraz klasztor, położone bliżej centrum miasteczka-M. B o r k ow s k a OSB, Klasztory dominikańskie..., s. $16 \mathrm{n}$.

${ }^{101}$ Akt fundacji klasztoru Dominikanek z 1677 r. zawiera ponadto obowiazek udziału w trzech ogólnych procesjach dróżkowych: w dniu Wszystkich Świętych (za zmarłych - wychodząca $\mathrm{z}$ ich kościoła), na Wniebowzięcie NMP (przychodząca do ich kościoła Domku Maryi) i trzecia w niedzielę, w oktawie Bożego Ciała (procesja obchodzona przez całe miasteczko) - M. B o r k ow s k a OSB, Klasztory dominikańskie..., s. 114.

${ }^{102}$ O. Jacek Burkwicz (zm, 1678), wcześniej znany jako autor i wydawca modlitewnika kalwaryjskiego pt. Prowiant duchowny na drogi święte kalwaryjskie..., Kraków 1662. Był również prowincjałem Prowincji Małopolskiej Bernardynów przez dwie kadencje. W 1670 r. jako prowincjał wraz z sekretarzem prowincji Franciszkiem Dzielowskim przyjmował fundacje Nowej Jerozolimy - W. F. M u r a w i e c, Burkwicz Jacek, [w:] Stownik polskich pisarzy franciszkańskich, Warszawa 1981, s. 77-78.

${ }^{103}$ O. Franciszek Dzielowski (1630-1681) był przełożonym w Kalwarii Zebrzydowskiej w latach 1662-1665, a potem w Krakowie na Stradomiu (1668-1671). Był także prowincjałem Prowincji Małopolskiej od roku 1680 - H. E. W y c zaw sk i, Dzielowski Franciszek, [w:] Stownik polskich pisarzy..., s. 121. 
pośrednictwem niniejszego zapisu do Akt Grodzkich starostwa czerskiego [A.D. 1672].

(Podpis fundatora)

(Miejsce na pieczęć)

(s. 131:) W Imię Pańskie. Amen. wprowadzenie ojców Bernardynów na wzgórze Nowej Kalwarii w R.P. 1670, w Niedzielę Palmową ${ }^{104}$.

V. Wspomożenie nasze w Imieniu Pana.

R. Który stworzył niebo i ziemię.

Ojcowie i bracia Bernardyni osobiście przybywający do tego miejsca idą procesjonalnie za wzniesionym wysoko krzyżem, odmawiając podniesio-

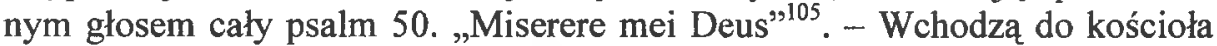
Najświętszej Maryi Dziewicy Wniebowziętej ${ }^{106}$. Prześwietny i Najprzewielebniejszy Ordynariusz miejsca i fundator $\mathrm{w}$ szatach pontyfikalnych, przed drzwiami kościoła do tej chwili zamkniętymi, udziela błogosławieństwa wchodzącym zakonnikom, a następnie wszyscy klękają i odmawiają: „Kirye eleison ... Pater noster ..., Ave Maria" 107 . Następnie Ordynariusz miejsca odmawia: „V. Salvos fac servos Tuos. R. Deus meus, sperantes in $\mathrm{Te}^{108}$. V. Deus custodiat introitum et exitum vestrum. R. Ex hoc nunc et usque in saeculum ${ }^{109}$. Oratio. Praetende, Domine famulis Tuis dexteram coelestis auxilii, ut Te toto corde perquirant et quae digne postulant, consequi maereantur. Per Christum Dominum Nostrum. Amen ${ }^{110}$.

Potem dał im klucze kościoła, „ut iisdem aperiatis, et claudatis, quibus et quando - oportet in Nomine Domini" (byście nimi otwierali i zamykali, kiedy będzie potrzeba). W końcu wręczywszy stułę wprowadził Bernardynów drzwiami kościoła otwartymi przez nich samych, mówiąc: „Wejdźcie do Domu Bożego, którego pobożnością do jego obsługiwania zostaliście wezwani, byśmy $\mathrm{z}$ pobożnym ludem byli godni wejść do życia wiecznego. Przez Chrystusa Pana Naszego". Z kolei, przychodząc do głównego ołtarza, po kolei całowali ręce lub nogi siedzącego przy ołtarzu ordynariusza miejsca. Potem pochylonym głęboko względnie leżącym na ziemi Bernardynom Biskup rozkazał zbliżyć się do oltarza ${ }^{11}$ i tu przez kolejny dotyk ołtarza rękami kapłanów,

${ }^{104}$ Niedziela Palmowa w 1670 r. przypadała w dniu 30 marca. - Chronologia polska..., s. 379 , tab. 16 .

${ }^{105}$ Miserere mei Deus - Zmiłuj się nade mną Panie.

${ }^{106}$ Chodzi tu o parafialny kościól Wniebowzięcia NMP przydzielony przez fundatora Bernardynom. W kilka lat później tytuł ten przeniesiono na kościół Dominikanów Obserwantów.

${ }^{107}$ Kirye eleison - Panie zmihuj się; Pater noster - Ojcze nasz; Ave Maria - Zdrowaś Maryjo.

${ }^{108} \mathrm{~W}$ thumaczeniu na język polski znaczy: „Zbaw sługi Twoje. Boże mój, w Tobie pokładające nadzieję".

109 "Niech Bóg strzeże waszego wejścia i wyjścia. Teraz i na wieki”.

110 "Modlitwa. Wyciagnij Panic prawicę niebieskiej pomocy dla sług Twoich, by Cię z całego serca szukali, i to o co godnie prosza, niech z łaski Twojej otrzymają. Amen".

${ }^{111} \mathrm{~W}$ oryginale lacińskim podano: „Ad planum altaris". 
przekazał im w posiadanie (świątynię), mówiąc: „Ja Stefan, Biskup z łaski Bożej poznanski wprowadzam was $w$ fizyczne i aktualne posiadanie tego kościoła i wszystkich kaplic tego miejsca i czynię was i ustanawiam rektorami, rządcami, protektorami i promotorami wszystkich Dróg kalwaryjskich Krzyża Chrystusa, wszystkich nabożeństw, oraz wszystkich Dróg współcierpienia i boleści Przenajświętszej Dziewicy Maryi, którymi będziecie zarządzali w taki sposób, by w dniu sądu zdać sprawę Bogu ze swego zarządzania. To uczyniwszy odśpiewali „Te Deum laudamus" ${ }^{\text {"12 }}$, przy wtórze organów, wraz z antyfoną i modlitwą do św. Franciszka z Asyżu. Kanonik poznański Mikołaj Popławski ${ }^{113}$ kaznodzieja królewski wygłosił przepiękne kazanie.

Potwierdza się (,Ita est”): Stefan Wierzbowski Biskup Poznański.

$$
\text { (Miejsce na pieczęć ordynariusza pozn.) （Podpis Biskupa pozn.) }
$$

\section{Ostateczne rozgraniczenie posiadłości fundacyjnych w Nowej Jerozolimie w 1679 r. dokonane:}

(s. 132:) My Stefan z Bożej łaski Biskup Poznański przejrzawszy i przeczytawszy list wyjaśniający S. Kongregacji Interpretacji Soboru Trydenckiego, przedłożony nam ... przeczytawszy też dokument fundacyjny ojców Bernardynów Prowincji Małopolskiej w Nowej Jerozolimie, w miejscu kościoła parafialnego (w Górze Kalwarii) przez nas wystawiony ... oddaliśmy oficjalnie w posiadanie, bez niczyjego sprzeciwu, protestu czy opozycji, wszystkie pomieszczenia rzeczonej fundacji. Dokonawszy uroczystego wprowadzenia, według obowiązującego zwyczaju, przewielebnych zakonnych ojców ${ }^{k}$ Bernardynów do kościoła we wspomnianym miejscu, naszym sumptem wraz z konwentem wybudowanego, oraz po dokładnym rozważeniu i przemyśleniu wszystkiego, chcemy, by rzeczona nasza fundacja (którą ustanowiliśmy, kierowani żarliwością i pobożnym afektem względem Ukrzyżowanego Zbawiciela, dając przemijające rzeczy na wiecznotrwałe) mogła trwać na wieczne czasy. A także rozwijać się obok miejsca dawnego kościoła parafialnego w Górze, a obecnie w Nowej Jerozolimie. Wspomnianym ojcom zakonu św. Franciszka Obserwantom Prowincji Małopolskiej, wraz ze swoimi przyległościami w opisanej wyżej fundacji wymienionymi oraz ich syndykowi generalnemu, przez nas łaskawie nadane, poniewaź kościół parafialny przenieśliśmy na Górę Kalwarii w tejże Nowej Jerozolimie położona i kapłanom świeckim Kongregacji św. Filipa Nereusza wraz z ich prepozytem przekazaliśmy z peł-

112 "Ciebie Boga wychwalamy".

113 Ks. Mikołaj Popławski (zm. 1711) kanonik poznański odznaczał się szczególnym nabożeństwem do św. Jana z Dukli, na którego cześć wygłosił kazanie w kościele Bernardynów św. Andrzeja we Lwowie w 1672 r. w obecności króla Michała Korybuta Wiśniowieckiego i jego żony, królowej Eleonory. (Kazanie to opublikowano w dziele Cypriana Damirskiego OFM, pt. "Thaumaturgus Russiae") Otrzymał pod koniec życia nominację na arcybiskupa lwowskiego (1710), ale nie doczekał się prekonizacji z Rzymu - A. P r z y b o ś, Popławski Mikotaj h. Drzewica, [w:] PSB, t. 27, s. 614. 
nym nadaniem uposażeniowym ${ }^{114}$. Na mocy danej nam przez Stolicę Apostolską władzy, uważamy, iż wspomniany wyżej ojciec zakonny Bonawentura Konopkowicz gwardian tegoż konwentu nowojerozolimskiego, który osobiście stawił się przed nami, a w jego osobie wszyscy ojcowie Zakonu Braci Mniejszych św. Franciszka de Observantia, wyżej wspomnianej Prowincji zakonnej, są w posiadaniu (opisanej fundacji), co niniejszym potwierdzamy. Wszystkie zaś braki, o ile by wokół tworzonej fundacji, w opisanych dokumentach pojawiły się, uzupełniamy, zatwierdzając je wyjaśniamy, iż powinna mieć moc wieczystej trwałości. Wszelkie pretensje, które by mieli księża Kongregacji św. Filipa Nereusza ze swym prepozytem, do dawnego uposażenia kościoła parafialnego, fundowanego na innym miejscu, my jako włodarze kościoła ...

(s. 133:) (wszelkie ich podstawy) anulujemy, usuwamy i odcinamy i nakładamy obowiązek wiecznego milczenia $w$ tych sprawach $^{115} \ldots$ Tych zaś zakonnych ojców (Bernardynów) oraz ich przełożonych mieszkających w tym konwencie zobowiązujemy do podjęcia wszystkich obowiązków (ciężarów) zaznaczonych $w$ dokumencie fundacyjnym, pod odpowiedzialnością zdania sprawy na sądzie Bożym ostatecznym. Celem zaś wyjaśnienia wątpliwości z fundacją zwiazzanych ... przede wszystkim tytuł dawny kościoła przenosimy do ojców św. Dominika, w tym sensie, żeby kościół tychże ojców cieszył się na przyszłość tytułem Wniebowzięcia chwalebnej Dziewicy Maryi ${ }^{116}$. Ten zaś stary kościół parafialny otrzyma tytuł Ofiarowania Najświętszej Maryi Panny. Użytkowanie zaś sadzawkil (?) zamieniamy na użytkowanie stawu owczego, ponieważ żadnej innej sadzawki nie ma na tym miejscu, ale tylko staw owczy. Użytkowanie stawu w sensie łowienia ryb, przyznajemy wyłącznie ojcom Bernardynom, zabraniając tegoż obywatelom miasta. Dajemy również w użytkowanie ojcom Bernardynom oba brzegi Wisły wraz z wszystkim co na nich się znajduje lub rośnie. Ponadto, co do użytkowania drzewa, wapna, kamieni etc., $\mathrm{z}$ wyjątkiem troski o przewóz na Wiśle ..., budowy spichlerzy i troski o magazynowanie wszelkich owoców, to wolne użytkowanie tychże pobrzeży oddajemy wraz z wszystkim, co na nich rośnie, ojcom Bernardynom, mocą naszego wpisu do akt urzędu grodzkiego, oraz niniejszego dekretu. Część lasów już wydzielona ze względu na budowę cegielni, niech zostanie wycięta ...

${ }^{114}$ Filipini (oficjalna nazwa: Oratorianie) otrzymali kościół parafialny Św. Krzyża na Górze Ukrzyżowania oraz osobne uposażenia nie pokrywające się w niektórych punktach $z$ nadaniami dawnego kościoła parafialnego. Otrzymali je bowiem w znacznej mierze Bernardyni. Por. przyp. 23.

${ }^{115}$ Ten „obowiazek wiecznego milczenia” (perpetuum silentium ... imponimus) został naruszony przez prepozyta tejże parafii, biskupa sufragana kijowskiego F. Zembrzuskiego w 1782 r. Rozpoczał on starania o przejęcie uposażen danych Bernardynom przez fundatora biskupa Stefana Wierzbowskiego.

${ }^{116}$ Chodzi tu już o nową siedzibę Dominikanów, kościół pod wezwaniem Wniebowzięcia NMP i konwent położony bliżej centrum Nowej Jerozolimy. Wschodnia granica posesji biegła „od Rogu oparkanionego Ogrodu, który leży przy Stajni królewskiej” wzdłuż parkanu „pomiędzy Ogrodem królewskim a Ogrodem rzeczonych oycow Dominikanów przedłużonym o Ogrojec Zbawiciela, aż do drugiego rogu Ogrodu niższego tychże wielebnych oycow Dominikanów, za kaplicą Apostołów Śpiących". - Akt fundacji klasztoru Dominikanów 11 października 1677. Aneks 2 [w:] M. B or k o w s k a OSB, Klasztory dominikańskie..., dz. cyt., s. 112, 113. 
Przewielebnym ojcom Bernardynom przydzielamy. Naniesione przez rzekę mady (z porostami) ${ }^{\prime}$ czyli „Wyspe" $\mathrm{z}$ całym swoim pokryciem i budynkiem na niej wystawionym naszym sumptem - ojcom Bernardynom przydzielamy i nadajemy. Użytkowanie zaś porostów czyli „,chrostu" ${ }^{\text {mm }}$ przeznaczamy do naprawy i konserwacji ogrodzenia (parkanu) królewskiego Zwierzyńca ... Co zaś tyczy się rozgraniczenia całości fundacji przydzielonej konwentowi ojców Bernardynów czyli ich prokuratorom i syndykom apostolskim, teraz i na wieczne czasy tu żyjącym, mocą wpisu do ksiag grodzkich w Czersku, uczynionego nadają moc wieczystej fundacji - częściowo zwiększając, częściowo zmniejszając, stosownie do uposażeń innych fundacji (czyniąc wcześniej stosowną rekompensatę). Przez to mocną, trwałą i odtąd niezmienną pragniemy ją uczynić. W taki to sposób ją ostatecznie opisujemy i oznaczamy granicami:

Najpierw zaczynając od rzeki Wisły, w tym miejscu, gdzie teraz stoi dom mieszczanina Wita Wioślarza (Przewoźnika) i granica południowa w górę idąc przy ogrodzeniu i zabudowaniach ostatnio wzniesionego Zwierzyńca i terenu Pałacu królewskiego, od ogrodu i sadu ojców Bernardynów środkiem przedzielonych (immediate divi dentia) aż do rogu stajni królewskiej", idąc dalej szeroką drogą publiczna, wzdhuż ogrodzenia. Następnie od samego rogu stajni $^{\mathrm{c}}$ królewskiej, idąc granicą zachodnią, tą samą szeroką drogą publiczną zwaną "Gościńcem Warszawskim" aż do kanału i kopca odgraniczającego fundację ojców Pijarów (Reverendis Patribus Scholarum Piarum) ${ }^{q}$ czyli „do Narożnika"" usypanego. Dalej od tegoż Narożnika, idąc linią prostą (granica) północną, traktem wzdhuż którego biegnie przekop na Wale (czyli Row) ${ }^{\mathrm{r}}$ aż do Wisły. W końcu granicą wschodnią, brzegiem Wisły, aż do domu wspomnianego Wita Przewoźnika włącznie, wraz z kaplicami św. Anny, św. Franciszka i św. Antoniego, Cegielnia, Browarem, Ważelnią soli, Młynem wodnym, Promem (Przewozem), użytkowaniem obu brzegów, z wszystkimi uposażeniami, polami, stawami, budynkami ..., podwładnymi kmieciami, ogrodnikami, stróżami oraz ich wszystkich czynszami, służebnościami i pracami, prawem, władzą (dominio) i tytułem dziedziczenia, użytkowaniem płodów, plonów, płatnościami (s. 134:) i z wszystkimi dodatkami i należnościami. Z wyjątkiem jednak jurysdykcji cywilnej i karnej ${ }^{\text {s }}$, która ze względu na spokój publiczny i dobro obywateli, całkowicie wszystkich i poszczególnych mieszkańców opisanych terenów fundacji, poddajemy magistratowi tegoż miasta (G. Kalwarii) ${ }^{\mathbf{t}}$ w dokumencie fundacyjnym szerzej określonych - nic nie rezerwując sobie, ani swoim spadkobiercom lub posiadaczom $\mathrm{z}$ wszelkiego innego tytułu. Wszystko nadajemy, przyznajemy, rezygnujemy na rzecz trwałości wieczystej i nieodwołalnej fundacji. Wprawdzie wobec tej fundacji z własnej woli Fundatora uczynionej, obecny tu o. Franciszek Kochanowski lektor teologii jubilat z Prowincji Małopolskiej, oraz definitor aktualny i w niniejszej sprawie komisarz ${ }^{117}$, w imieniu całej zakonnej Prowincji Małopolskiej, publicznie i wyraź-

${ }^{117}$ Franciszek Kochanowski h. Korwin był młodszym bratem Dominika Kochanowskiego. Obaj byli bernardynami. Dominik opracował dzieło mariologiczne o Niepokalanym Poczęciu NMP pt. „Novus asserendae ...modus” (Kraków 1669), którego publikacją po śmierci autora zajął się Franciszek poszerzając całość o własne przemyślenia teologiczne i dedykując królowi 
nie (clara voce) zaprotestował, iż pamiętając na ubóstwo nakazane Regułą Serafickiego Ojca Patriarchy św. Franciszka" nie chce przyjąc wieczystej dominacji nad wydzielonymi terenami fundacji i ich mieszkańcami, ale tylko użytkowania czasowego ${ }^{118}$, dopóki konwent $\mathrm{z}$ kościołem i innymi zabudowaniami, budowanymi dla wygody braci, trudem ... wieśniaków oraz ich czynszami przygotowane (nie zostaną ukończone). Uroczyście przyrzekając w swoim imieniu oraz swoich braci, pragnie zrezygnować z tych wszystkich budowli oraz terenów rozgraniczonych, $i$ oddaje $w$ posiadanie realne syndykowi apostolskiemu na ufundowanie wieczyste i utrzymanie orkiestry ,graczy i bębnisty $^{\text {'w }}$ na tyle, na ile każdy $\mathrm{z}$ nich będzie potrzebował na utrzymanie, ubranie etc. ... tak jednak, by posiadanie i zarządzanie funduszami, włościanami, ich pracami i czynszami z wszelkim prawem patrymonialnym (zwierzchnim [iure dominii] $^{\mathbf{x}}$, własnościowym, użytkowaniem wraz $\mathrm{z}$ wszelkiego rodzaju dochodami ... Należy tu trawa dla wypasu bydła wraz z uprawami [jażyn] ${ }^{y}$, użytkowanie obu brzegów Wisły ze względu na przewóz rzeczny, ważelnia, młyn wodny, browar, cegielnia oraz inne oficyn wybudowane dla wygody i konserwacji konwentu) niech należą całkowicie do syndyków apostolskich i niech żadna część nadania fundacyjnego nie zostanie przekazana w obce ręce, szczególnie szlachty, ani też nie zostanie zamieniona. Nieporozumienia w sprawie własności terenu, na których zostały wybudowane domy Giarskich (Górskich?) i Wierzbowskich (małżonków) ..., umarzając sprawę orzekamy, iż konwent nie powinien rościć sobie w stosunku do nich swoich praw własnościowych. Oceniamy to w ten właśnie sposób na wieczne czasy. Wszystko to w punktach szczegółowych (klauzulach) autorytetem apostolskim, udzielonym nam w tej sprawie - postanawiamy, dekretujemy i rozporządzamy. I podporządkowanie się ojców Bernardynów (naszej woli) przyjmujemy jako trwające na wieczne czasy.

Działo się w Nowej Jerozolimie, w dniu 12 czerwca R.P. 1679 w obecności Przewielebnych: Jana Kazimierza z Bnina Opalińskiego ${ }^{\mathbf{z}}$ Biskupa nominata koadjutora naszego biskupstwa poznańskiego ${ }^{119}$; opata bledzewskiego; sekretarzy królewskich: Zygmunta Otrembosza kanonika poznańskiego i warszawskiego; Waleriana Boczkowskiego kanonika poznańskiego, warszawskiego kanclerza .

Michałowi Korybutowi Wiśniowieckiemu. Stąd jest uważany za współautora dzieła. Zmarł w Krakowie w 1686 r. - H. E. W y c z a w s k i OFM, Kochanowski Franciszek, [w:] PSB, t. 13, s. 182-183; tenże, Kochanowski Franciszek, [w:] Stownik polskich pisarzy franciszkańskich, Warszawa 1981, s. 227-228.

${ }^{118}$ Rezygnacja Kochanowskiego w imieniu prowincji zakonnej z posiadania nadań uposażeniowych, jako niezgodnego $\mathrm{z}$ regułą św. Franciszka, miała charakter ściśle ograniczony. Odnosiła się tylko do praw własnościowych zakonu, nad wszystkimi nieruchomościami, którymi od tej pory miał zarządzać w imieniu Stolicy Apostolskiej tzw. syndyk apostolski, wydzielać konwentowi fundusze konieczne na budowy, remonty i utrzymanie zakonników.

${ }^{119}$ Kazimierz Jan Opaliński (Opaleński) był koadjutorem biskupa poznańskiego Stefana Wierzbowskiego (od 1677) z prawem następstwa, oraz kanclerzem kurii $w$ Poznaniu i opatem bledzewskim. W 1681 r. został biskupem chelmińskim. - J. Now a ck i, Dzieje archidiecezji poznańskiej, t. 2, s. 108; E. P i s z c z, Opaliński Kazimierz Jan z Bnina h. Lodzia, [w:] PSB, t. 24, s. 85, 86. 


\author{
Stefan Wierzbowski \\ bp poznański \\ (miejsce na pieczęć) \\ (Podpisany:) \\ Stanisław Warszycki \\ kasztelan krakowski, syndyk ap. gen. Prowincji Małopolskiej ${ }^{120}$
}

Fundacja ta została oddana do oblaty w Grodzie Czerskim we wtorek, w dniu św. Jadwigi Śląskiej (15 października) R. P. $1754^{121}$.

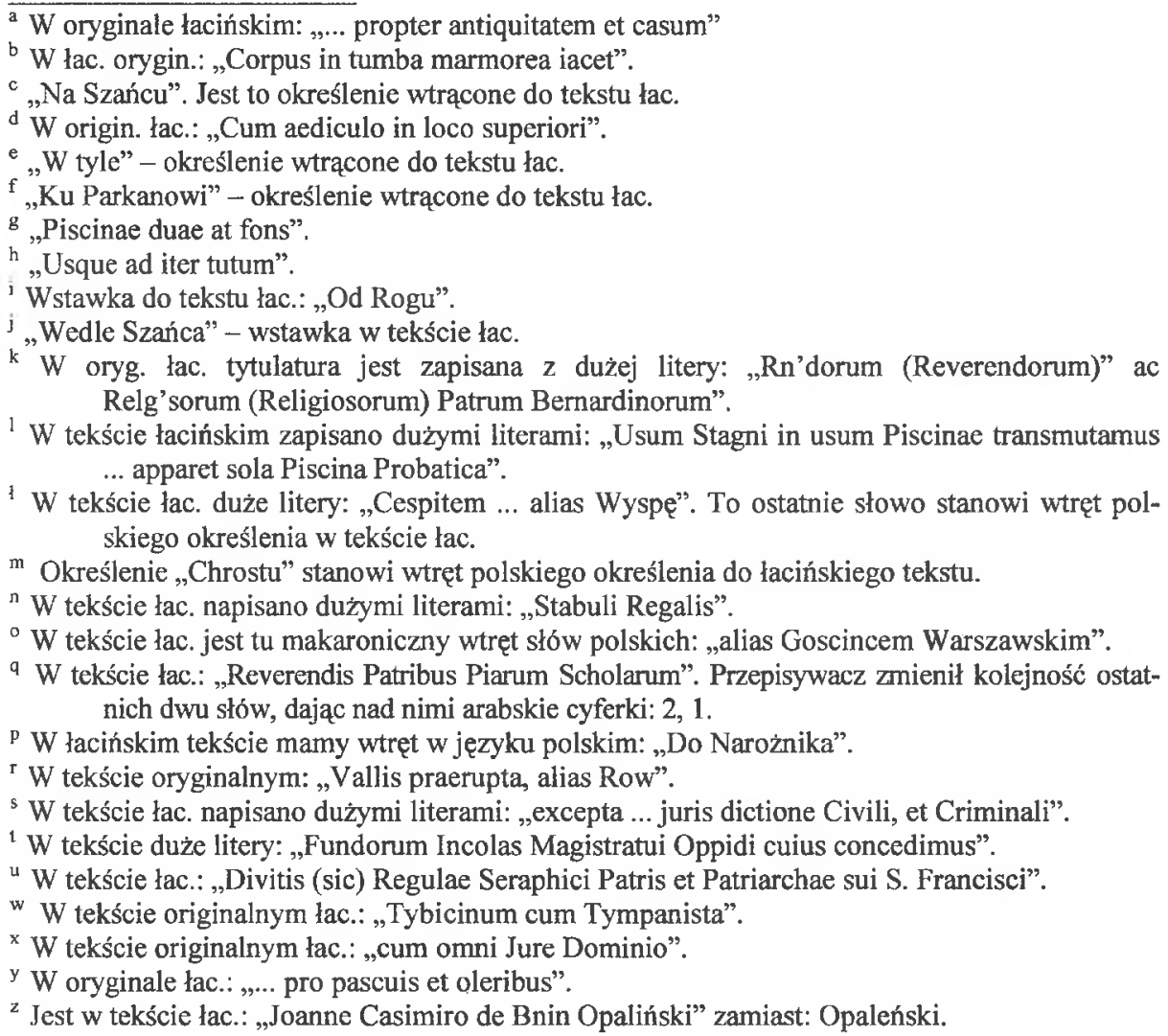

${ }^{120}$ Zob. przyp. 95.

${ }^{121}$ Ustalono według Chronologii polskiej, pod red. B. Włodarskiego (W. 1957, s. 241). 